\title{
Molecular Pathogenesis of Cholangiocarcinoma
}

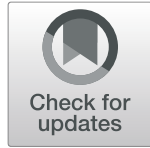

Peter L. Labib* (D), George Goodchild and Stephen P. Pereira(D)

\begin{abstract}
Background: Cholangiocarcinomas are a heterogeneous group of malignancies arising from a number of cells of origin along the biliary tree. Although most cases in Western countries are sporadic, large population-based studies have identified a number of risk factors. This review summarises the evidence behind reported risk factors and current understanding of the molecular pathogenesis of cholangiocarcinoma, with a focus on inflammation and cholestasis as the driving forces in cholangiocarcinoma development.

Risk Factors for cholangiocarcinogenesis: Cholestatic liver diseases (e.g. primary sclerosing cholangitis and fibropolycystic liver diseases), liver cirrhosis, and biliary stone disease all increase the risk of cholangiocarcinoma. Certain bacterial, viral or parasitic infections such as hepatitis B and C and liver flukes also increase cholangiocarcinoma risk. Other risk factors include inflammatory disorders (such as inflammatory bowel disease and chronic pancreatitis), toxins (e.g. alcohol and tobacco), metabolic conditions (diabetes, obesity and non-alcoholic fatty liver disease) and a number of genetic disorders.

Molecular pathogenesis of cholangiocarcinoma: Regardless of aetiology, most risk factors cause chronic inflammation or cholestasis. Chronic inflammation leads to increased exposure of cholangiocytes to the inflammatory mediators interleukin-6, Tumour Necrosis Factor-a, Cyclo-oxygenase-2 and Wnt, resulting in progressive mutations in tumour suppressor genes, proto-oncogenes and DNA mismatch-repair genes. Accumulating bile acids from cholestasis lead to reduced $\mathrm{pH}$, increased apoptosis and activation of ERK1/2, Akt and NF-kB pathways that encourage cell proliferation, migration and survival. Other mediators upregulated in cholangiocarcinoma include Transforming Growth Factor- $\beta$, Vascular Endothelial Growth Factor, Hepatocyte Growth Factor and several microRNAs. Increased expression of the cell surface receptor c-Met, the glucose transporter GLUT-1 and the sodium iodide symporter lead to tumour growth, angiogenesis and cell migration. Stromal changes are also observed, resulting in alterations to the extracellular matrix composition and recruitment of fibroblasts and macrophages that create a microenvironment promoting cell survival, invasion and metastasis.

Conclusion: Regardless of aetiology, most risk factors for cholangiocarcinoma cause chronic inflammation and/or cholestasis, leading to the activation of common intracellular pathways that result in reactive cell proliferation, genetic/epigenetic mutations and cholangiocarcinogenesis. An understanding of the molecular pathogenesis of cholangiocarcinoma is vital when developing new diagnostic biomarkers and targeted therapies for this disease.
\end{abstract}

Keywords: Cholangiocarcinoma, Aetiology, Pathology, Inflammation, Cholestasis, Molecular pathogenesis, Biomarkers

\footnotetext{
* Correspondence: peter.labib.16@ucl.ac.uk

UCL Institute for Liver and Digestive Health, University College London

(Royal Free Hospital Campus), Royal Free Hospital, Pond Street, London NW3

2QG, UK
}

(C) The Author(s). 2019 Open Access This article is distributed under the terms of the Creative Commons Attribution 4.0 International License (http://creativecommons.org/licenses/by/4.0/), which permits unrestricted use, distribution, and reproduction in any medium, provided you give appropriate credit to the original author(s) and the source, provide a link to the Creative Commons license, and indicate if changes were made. The Creative Commons Public Domain Dedication waiver (http://creativecommons.org/publicdomain/zero/1.0/) applies to the data made available in this article, unless otherwise stated. 


\section{Background}

Cholangiocarcinomas are a heterogeneous group of malignancies that occur at any location along the biliary tree [1]. They are anatomically classified as intrahepatic (arising proximal to the second order bile ducts), perihilar (arising between the second order bile ducts and the insertion of the cystic duct into the common bile duct) and distal extrahepatic (arising between the insertion of the cystic duct and the ampulla of Vater) [2]. Although this anatomical classification is widely used, other factors such as tumour growth pattern (mass-forming, periductal infiltrating or intraductal) and the cell of origin (cholangiocytes, peribiliary glands, hepatic progenitor cells or hepatocytes) provide alternative methods of classification that may better predict tumour behaviour [1, 3, 4]. Worldwide, the incidence of intrahepatic cholangiocarcinoma may be increasing whereas perihilar and distal extrahepatic cholangiocarcinomas are decreasing [5]. Incidence rates vary significantly in different countries, probably due to genetic differences and geographical variations in risk factors. In Western Europe, incidences range from 0.45 per 100,000 in Switzerland to 3.36 per 100,000 in Italy [6]. The highest incidence rates are in Asia due to the prevalence of liver fluke infections (e.g. 85 per 100,000 in Northeast Thailand) [5]. Historical under-reporting of cholangiocarcinoma [7], geographical variations in data recording and misclassification of different sub-types means that cancer registry data - and therefore trends in incidence - should be interpreted with caution [8].

The well-described hypothesis of the adenoma-dysplasia-carcinoma sequence observed in many other cancers has not yet been fully characterised in cholangiocarcinoma, due in part to the varying cells of origin that can cause the disease. Intraductal papillary neoplasms of the bile duct demonstrate stepwise progression of oncogenic molecular pathways and increasing dysplasia highly suggestive of an adenoma to carcinoma sequence [9]. Biliary intraepithelial neoplasia, a classification that describes the corresponding molecular and histological changes seen in flat lesions of the bile duct arising from cholangiocytes and peribiliary glands, provides further evidence for such a sequence [10]. This review summarises the risk factors and molecular pathogenesis of cholangiocarcinoma, with a focus on inflammation and cholestasis as the driving forces in cholangiocarcinoma development.

\section{Risk factors}

Although most cases of cholangiocarcinomas in Western countries are considered sporadic [11], there are a number of well-described risk factors (Table 1) [9, 12-24]. It is proposed that many of these risk factors cause chronic inflammation and cholestasis, resulting in a cycle of
Table 1 Risk factors for cholangiocarcinoma

\begin{tabular}{ll}
\hline Risk factors for cholangiocarcinoma \\
\hline Cholestatic liver & Primary Sclerosing Cholangitis (PSC) \\
& Fibropolycystic liver diseases \\
& Congenital hepatic fibrosis \\
& Caroli disease \\
& Choledochal cysts \\
& Biliary hamartomas \\
Liver cirrhosis (any aetiology) & Cholecystolithiasis \\
disease & Hepatolithiasis \\
& Choledocholithiasis \\
Liver flukes & Hepatitis B and C \\
Chronic typhoid disease & Recurrent pyogenic cholangitis \\
Mether & Human Immunodeficiency Virus (HIV) \\
Intraductal Papillary Neoplasms of the Bile duct \\
(IPNB)
\end{tabular}

reactive cell proliferation, genetic and epigenetic mutations and eventual cholangiocarcinogenesis [25].

\section{Cholestatic liver diseases}

Primary Sclerosing Cholangitis (PSC) is a chronic cholestatic liver disease of unclear aetiology characterised by progressive destruction of the intra- and extrahepatic bile ducts. PSC is strongly associated with inflammatory bowel disease; $60-80 \%$ of patients with PSC have a history of ulcerative colitis and $7-21 \%$ have a history of Crohn's disease [26]. Patients with PSC have a 15\% lifetime incidence of cholangiocarcinoma (equivalent to a 398-fold increased risk compared to the general population) and up to one third will develop cholangiocarcinoma 
within a year of being diagnosed with PSC [27, 28]. It is proposed that cholestasis leads to overexposure of cholangiocytes to bile acids that cause abnormal cell proliferation and cholangiocarcinogenesis. Experimental models have shown that bile acids can phosphorylate Epidermal Growth Factor Receptor (EGFR) in cholangiocarcinoma and immortalised cholangiocyte cell lines, leading to cell growth and proliferation [29]. As PSC causes cholestasis, the prolonged exposure of cholangiocytes to bile is likely to be a significant factor in cholangiocarcinogenesis in this disease.

The Fibropolycystic Liver Diseases (FPLD) are a group of conditions characterised by cystic lesions in the liver that are often associated with liver fibrosis and/or renal abnormalities [30]. They arise as a result of abnormal development of the embryonic sheet of biliary precursor cells (the ductal plate) that form the intrahepatic bile ducts and cholangiocytes [31]. FPLD includes congenital hepatic fibrosis, Caroli disease, choledochal cysts and biliary hamartomas [30]. These diseases collectively have a 15\% risk of developing cholangiocarcinoma [32]. However, the risk of malignant transformation in FPLD varies depending on the diagnosis; the lifetime risk in patients with choledochal cysts is $15-20 \%$ [33], whereas cholangiocarcinogenesis secondary to biliary microhamartomas is rare and it is still debatable as to whether or not it is a true risk factor for the disease [34]. The increased risk is likely to be due to chronic inflammation secondary to impaired biliary drainage, leading to overexposure of cholangiocytes to bile acids and deconjugated carcinogens that were previously conjugated in the liver, reflux of pancreatic secretions into the bile duct, and bacterial contamination $[35,36]$.

\section{Liver cirrhosis}

Liver cirrhosis is characterised by diffuse fibrosis and nodule formation that occurs as a result of chronic liver injury [37]. The causes of cirrhosis are numerous and include alcohol-associated cirrhosis, non-alcoholic steatohepatitis (NASH), viral hepatitis and autoimmune hepatitis as well as a number of metabolic, congenital and toxic causes [37]. Regardless of aetiology, a number of population-based studies have found cirrhosis to be associated with an increased risk of intrahepatic cholangiocarcinoma [2]. A meta-analysis in 2012 (seven case-control studies, $n=339,608$ ) found cirrhosis to have an Odds Ratio (OR) of 22.9 (95\% Confidence Interval (CI) 18-2-28.8) for intrahepatic cholangiocarcinoma (ICC) [38]. This may be due to the tissue microenvironment seen in cirrhosis (chronic inflammation, increased cell turnover and progressive fibrosis), which is very similar to the microenvironments seen in a number of other high risk conditions such as PSC [39]. Interestingly, a recent retrospective analysis by Petrick et al. from the US-based Surveillance, Epidemiology, and End Results (SEER) database (2092 ICC, 2981 extrahepatic cholangiocarcinomas (ECC), 323,615 controls) found nonspecific cirrhosis to be associated with both ICC and ECC (ICC OR 8.26, 95\% CI 6.83-9.99; ECC OR 3.83, 95\% CI 3.05-4.80) [40]. Whilst the liver microenvironment can explain the increased risk in ICC, it is harder to conclude that the same mechanism is responsible for the increased risk of ECC. It may be partly explained by the observation that cirrhosis is linked to lower levels of bile acid excretion, which leads to gut microbiome dysbiosis, a decrease in normal gut microbiata and an increase in pro-inflammatory and pathogenic species which may in turn lead to bacterial contamination of the biliary tree [41, 42]. A confounding factor common to many retrospective analyses is inaccuracy in the anatomical classification of cholangiocarcinoma; many of the cases of ECC are likely to have been perihilar cholangiocarcinomas, which due to their proximity to the liver parenchyma are more likely to be affected by the hepatic microenvironment.

\section{Biliary stone disease}

Gallstones are one of the most common digestive pathologies in the Western world with a prevalence of $10-20 \%$ [43]. Usually composed predominantly of cholesterol, they can be found within the gallbladder (cholecystolithiasis), the extrahepatic bile duct (choledocholithiasis) or within the intrahepatic biliary tree (hepatolithiasis). Gallstones are associated with an increased risk of both ICC and ECC [40]. In the aforementioned SEER analysis by Petrick et al., choledocholithiasis was found to confer an OR of 6.94 (95\% CI 5.64-8.54) for ICC and 14.22 (95\% CI 12.48-16.20) for ECC. Cholecystolithiasis conferred a lower but still significantly increased risk for cholangiocarcinoma (OR 3.93 (95\% CI 3.49-4.43) and 5.29 (95\% CI 4.83-5.80) for ICC and ECC respectively). An interesting relationship between cholecystectomy and increased risk of cholangiocarcinoma has been observed, although whether or not this is causative remains unclear. A recent systematic review and meta-analysis analysed the data from 4 cohort studies and 12 case-control studies ( $n=220,376$ patients with cholecystectomy, 562,392 controls) and found cholecystectomy to be associated with an increased risk for ECC (OR 2.31, 95\% CI 1.34-3.28) but not ICC (OR 1.40, 95\% CI 0.94-1.87) [44]. One causative mechanism could be the observed change in bile salt composition seen after cholecystectomy where there is a reduction in the circulating pools of primary bile salts but a maintained pool of deoxycholic acid, which is associated with cholangiocyte proliferation (see Cholestasis and bile acids below) [29, 45]. It is also possible that the increased risk is secondary to gallstone disease rather than the procedure itself. This is supported by the observation that the 
increased risk of cholangiocarcinoma reduces to that of the baseline population within ten years of cholecystectomy [46].

Hepatolithiasis, more commonly found in East Asia and associated with liver fluke infections [47] and Caroli disease [48], is also a well-established risk factor for cholangiocarcinoma [49]. A Nationwide multi-institutional cross-sectional survey in Japan in 2006 identified 325 patients with hepatolithiasis, 23 of which having developed cholangiocarcinoma (7\%) [50]. The increased risk is thought to be secondary to cholestasis from impaired biliary drainage and inflammation secondary to liver flukes and recurrent bacterial infections $[49,51]$.

\section{Chronic infections}

Liver fluke infections are endemic in China, Thailand, Korea, Vietnam, Laos, and Cambodia [52]. Cholangiocarcinoma is associated with infection with Clonorchis sinensis, Opisthorchis viverrini and Opisthorchis felineus species, which are usually transmitted through the consumption of raw or undercooked freshwater fish. Mechanical damage from the flukes' oral and ventral hooks, excreted metabolic products, and granulomatous inflammation surrounding fluke eggs embedded within the periductal tissue all lead to fibrosis and chronic inflammation that results in DNA damage and carcinogenesis $[52,53]$.

Chronic infection with Hepatitis B and C viruses account for $57 \%$ of cases of cirrhosis globally [54]. Several meta-analyses show an increased risk of ICC in both hepatitis $B$ and hepatitis $C$ infection [55-57]. The association with hepatitis $C$ is stronger in regions where hepatitis $C$ is endemic, and likewise for hepatitis $B$ [58]. The largest meta-analysis (13 case-control studies and three cohort studies, $n=202,135$ and $n=2,655,902$ respectively) found hepatitis B to have an OR of $3.17(95 \%$ CI 1.99-5.34) and hepatitis C an OR of 3.42 (95\% CI 1.96-5.99) [55].

Chronic typhoid carriers carry a six-fold increase for cholangiocarcinoma [20]. A retrospective analysis of 440 cases of hilar cholangiocarcinoma from a single centre in Egypt (1995-2004) found 52\% of patients had a history of typhoid infection, although $54 \%$ of patients were also hepatitis $\mathrm{C}$ positive, another significant risk factor that could account for part of the increased risk observed [59].

Recurrent Pyogenic Cholangitis (RPC), more commonly encountered in Southeast Asia, is characterised by recurrent primary bacterial infections of the biliary tree resulting in the development of pigment stones and stricturing of the bile ducts [60]. Possible causes are co-infection with liver flukes or breakdown of conjugated bilirubin by bacterial enzymes causing the formation of pigment stones leading to hepatolithiasis, although the evidence for these proposed aetiologies remains sparse $[60,61]$. One retrospective study from the US (42 patients, 1986-2005) found $12 \%$ of patients developed cholangiocarcinoma, although it is difficult to know if these patients had RPC or hepatolithiasis with recurrent secondary biliary infection. In either case, biliary stone disease associated with recurrent cholangitis is likely to increase the risk of cholangiocarcinoma.

Human Immunodeficiency Virus (HIV) infection may increase the risk of ICC [62]. A U.S. case-control study (625 cases, 90,834 controls) found HIV to have an OR of 5.9 (95\% CI 1.8-18.8) [63]. HIV is known to be associated with an increased risk of cholangitis either directly (as part of AIDS cholangiopathy) or indirectly via other opportunistic infections such as cytomegalovirus [63]. It is important to note that this data came from the preand early combined antiretroviral therapy era, and multiple relevant confounding diseases with known risk for cholangiocarcinoma were significantly more prevalent in the case population (non-specific cirrhosis, alcoholic liver disease, hepatitis $\mathrm{C}$, diabetes and inflammatory bowel disease). It is therefore possible that the risk of cholangiocarcinoma from HIV is overstated.

Regardless of the pathogen, all of the above infections are characterised by chronicity of infection and sustained inflammation directly or indirectly affecting the biliary tree, leading to mutagenesis, cell proliferation and cancer development.

\section{Inflammatory disorders}

Several inflammatory conditions have been linked to the development of cholangiocarcinoma. Inflammatory bowel disease (IBD) - through its association with PSC - is a risk factor for the development of cholangiocarcinoma. Cholangiocarcinoma occurs at a younger age in IBD patients than in the general population (56 years vs 71 years, respectively). In Western countries, cholangiocarcinoma occurring in patients $<40$ years is almost always associated with IBD $[64,65]$. PSC-associated cholangiocarcinoma in the presence of IBD appears to follow the dysplasia-carcinoma sequence [66]. The evolution from PSC to cholangiocarcinoma might result from DNA damage by biliary inflammation and bile acids in IBD patients with altered DNA repair functions $[67,68]$. Immunosuppression as a result of IBD treatment may also be a contributor in IBD-related carcinogenesis [69].

Two other conditions that may be associated with cholangiocarcinoma are chronic pancreatitis and gout [40]. The mechanisms underlying this may be related to common pathways of chronic inflammation and/or gut microbiome dysbiosis [70-72]. Thyrotoxicosis has been linked to the development of ICC but not ECC (OR 
1.25, 95\% CI 1.01-1.54) [40]. Untreated hyperthyroidism is known to be associated with abnormal liver function; possible mechanisms include genetic polymorphisms, oxidative stress, and cholestasis secondary to hepatic microcirculatory disorders and damage to hepatocyte and endothelial cell membranes [73-76].

\section{Toxins}

There has been conflicting evidence on the risk of alcohol and tobacco consumption, largely due to the data coming from multiple study designs including population-based, cohort and case-control studies. A recent meta-analysis of 14 cohort studies $(n=1,515,741$ with 410 cases of ICC) found heavy alcohol consumption ( $\geq 5$ drinks/day) conferred a hazard ratio of 1.68 , although the $95 \% \mathrm{CI}$ was $0.99-2.86$ [77]. In contrast, a meta-analysis in 2012 of 11 case-control studies ( $n=3374$ ICC, 394,774 controls) found heavy alcohol consumption ( $>80 \mathrm{~g} /$ day or alcoholic liver disease) to confer an OR of 2.81 (95\% CI $=1.52-5.21)$ [38]. This disparity is likely due to the different design methodologies of the included studies; alcohol consumption has been shown to be more strongly associated with liver cancer in case-control studies [78] and cohort studies tend to ask participants about recent alcohol consumption, unlike case-control studies that often estimate lifetime alcohol consumption [77]. Although a meta-analysis in 2013 (six case-control studies, one cohort study) found no difference in cholangiocarcinoma risk between drinkers and non-drinkers (OR 1.09, 95\% CI 0.87-1.37), the recent SEER analysis by Petrick et al. found patients with alcohol-related disorders to have an increased risk of cholangiocarcinoma (OR 2.60, 95\% CI 2.23-3.04) [40, 79]. Whilst it is likely that alcohol increases the risk of ICC through direct chronic hepatic injury and cirrhosis, the mechanism underlying an increased risk for ECC remains unclear.

Smoking also increases the risk of both ICC (OR 1.46, 95\% CI 1.28-1.66) and ECC (OR 1.77, 95\% CI 1.59-1.96) [40]. It has been proposed that carcinogenic tobacco compounds damage the biliary epithelium through direct exposure via the circulation [79].

Thorotrast (thorium oxide) was a radiological contrast agent used from 1930-1960 [22]. This compound conferred a 300-fold increased risk of developing cholangiocarcinoma with a latency period of up to 45 years after exposure [80]. Although the mechanism has not been fully elucidated, it is known that Thorotrast is taken up into the reticuloendothelial system and contains an emitter of $\alpha$-radiation [81]. Combined with its exceptionally long half-life of 400 years, it is likely that chronic exposure to $\alpha$-radiation lead to direct DNA damage and carcinogenesis.
Exposure to chemical toxins has been linked to outbreaks of cholangiocarcinoma in Italy, West Virginia, and British Columbia, although convincing evidence is lacking [82]. Possible culprits include dioxins, vinyl chloride, nitrosamines, asbestos, the oral contraceptive pill and isoniazid [36, 83, 84].

\section{Metabolic conditions}

Diabetes increases the risk of ICC and ECC [12, 40, 85]. A meta-analysis in 2015 (15 case-control studies and 5 cohort studies, 10,362 patients with cholangiocarcinoma and 351,908 controls) found a combined OR of 1.74 (95\% Confidence Interval (CI): 1.62-1.87), although a certain degree of heterogeneity was seen in subgroup analyses of the populations [85]. The recent meta-analysis by Petrick et al. analysed the risk of Type I and Type II diabetes separately and found raised ORs for both ICC and ECC (Type I diabetes OR 1.43 for ICC and 1.30 for ECC, Type II diabetes OR 1.54 for ICC and 1.45 for ECC [40]. All lower values for 95\% CI >1.0) [40]. Obesity was also shown to be associated with ICC and ECC, although the OR was greater for ICC (ICC OR 1.42 (95\% CI 1.21-1.66), ECC OR 1.17 (95\% CI 1.01-1.35)). These findings are consistent with a previous meta-analysis that found obesity to confer an OR of 1.37 (95 \% CI 1.22-1.55) for cholangiocarcinoma, although no sub-analysis between ICC and ECC was performed [86].

A new discovery from two recent meta-analyses is the association between Non-Alcoholic Fatty Liver Disease (NAFLD) and cholangiocarcinoma [40, 87]. NAFLD is defined as the presence of hepatic steatosis in the absence of other causes of hepatic fat accumulation (e.g. excessive alcohol consumption, hypothyroidism, etc.) [88]. This can occur in the absence (Non-Alcoholic Fatty Liver, NAFL) or presence (Non-Alcoholic Steatohepatitis, NASH) of inflammation. Non-alcoholic fatty liver disease confers a roughly 3 -fold increase in the risk of ICC (OR 3.52, 95\% CI 2.87-4.32) and ECC (OR 2.93, 95\% CI 2.42-3.55) [40].

There are several proposed causative mechanisms for the inter-related risk factors of diabetes, obesity and NAFLD. Leptin, the hormone responsible for the sensation of satiety, is over-excreted when there is excess adipose tissue and has been shown to enhance cholangiocarcinoma cell growth [89]. Excess adipose tissue causes low-grade systemic inflammation through the release of inflammatory cytokines such as Interleukin-6 (IL-6) and Tumour Necrosis Factor-a (TNFa) resulting in chronic hepatic inflammation, cirrhosis and fibrosis [90]. This low grade systemic inflammation is believed to contribute to the onset of insulin resistance and subsequent development of Type II diabetes [40]. The insulin resistance seen in NAFLD, diabetes and obesity 
results in compensatory systemic hyperinsulinaemia and increased Insulin-like Growth Factor-1 (IGF-1) production in the liver [91, 92]. IGF-1 binding to its receptor (IGF1-R) leads to upregulation of genes involved in cell proliferation and survival [93]. A supporting study for this mechanism by Alvaro et al. found that cholangiocytes from biopsies of normal livers $(n=10)$ do not express significant levels of IGF-1 or IGF1-R on immunohistochemical staining, but are both intensely expressed in biopsies of cholangiocarcinoma $(n=18)$ [94]. The association between Type I diabetes and cholangiocarcinoma may be explained by the high prevalence of NAFLD (45\%) in patients with Type I diabetes [95]. In conclusion, all three conditions are characterised by hepatic steatosis, chronic inflammation, insulin resistance and subsequent upregulation of genes promoting cell turnover, which are all likely to contribute to cholangiocarcinogenesis.

\section{Genetic diseases}

Lynch syndrome (previously known as hereditary non-polyposis colorectal cancer) is an autosomal dominant disorder caused by a germline mutation of one of the four DNA mismatch repair genes. This results in an increased risk of cancers, most commonly colorectal and endometrial cancers but also cancers of the upper gastrointestinal tract, urinary tract and brain. Lifetime risk of a pancreatic or biliary tract cancer is estimated at $2 \%$, although data on cholangiocarcinoma specifically are lacking [96].

A number of congenital abnormalities confer a higher risk for developing cholangiocarcinoma. Defects in genes coding for bile salt transporter proteins (BSEP/ABCB11, FIC1/ATP8B1 and MDR3/ABCB4) cause cholestasis leading to the release of inflammatory cytokines, chronic inflammation and subsequent cholangiocarcinogenesis [97].

\section{Intraductal Papillary Neoplasms of the Bile Duct (IPNB)}

IPNB (previously known as biliary papillomatosis) is a rare disease characterised by the presence of multiple papillary adenomas within the bile ducts. It is associated with hepatolithiasis and liver fluke infection in Asian countries (but not in Western countries) implying both genetic and environmental aetiologies [98]. IPNBs have a high risk of malignant transformation to cholangiocarcinoma, estimated to be as high as $40-80 \%$.

\section{Pathogenesis}

Although the above risk factors cover a diverse range of diseases, recurring pathological features in almost all of them are chronic inflammation and/or cholestasis. These two features can provide a unified pathway for the molecular pathogenesis of cholangiocarcinoma by acting on a series of intracellular pathways that encourage carcinogenesis (Fig. 1). Whilst this is unlikely to be a complete model, many of the pathways described below are involved in cholangiocarcinogenesis.

\section{Inflammation}

Inflammation is one of the key factors in cholangiocarcinogenesis. High concentrations of inflammatory mediators cause progressive mutations in tumour suppressor genes, proto-oncogenes and DNA mismatch-repair (MMR) genes, resulting in cell proliferation [99].

The inflammatory cytokine Interleukin-6 (IL-6) affects multiple intracellular pathways that contribute to cholangiocarcinogenesis and can be highly overexpressed in both cultured cholangiocarcinoma cell lines and surgically resected specimens [100]. In normal cholangiocytes, a negative feedback loop for IL-6 exists (IL-6 activates the JAK-STAT pathway, increasing transcription of the cytokine suppressor SOCS3 [99]. In cholangiocarcinoma, epigenetic silencing of SOCS3 is observed, reducing the negative feedback [101]. IL-6 also downregulates specific microRNAs resulting in increased transcription of DNMT1 (an enzyme used to methylate cytosine to alter gene expression) resulting in decreased expression of tumour suppressor genes (see 'microRNA changes' below) [102]. By activating STAT3 (a transcription factor in the STAT protein family), IL-6 upregulates Mcl-1 (an apoptosis inhibitor) preventing cell death [103]. IL-6 increases expression of progranulin, a precursor protein for granulins (a family of peptides that regulate cell growth) resulting in activation of the Akt pathway which mediates cell survival, mitosis, migration and angiogenesis [99, 104]. Interestingly, the liver fluke $O$. viverrini secretes a granulin homologue $(O v-\mathrm{GRN}-1)$ that can activate the Akt pathway directly resulting in cell proliferation and angiogenesis [105-107]. IL-6 also activates p38 MAPK (a group of protein kinases responsible for cell differentiation and proliferation), resulting in decreased expression of p21 (a mediator of cellular senescence) resulting in mitosis [108]. Lastly, IL-6 reduces telomere shortening by increasing telomerase activity during mitosis, prolonging cell survival [109].

The inflammatory cytokine TNF $\alpha$ causes upregulation of Activation-Induced cytidine Deaminase (AID), an enzyme that creates DNA mutations by converting cytosine to uracil. This results in multiple somatic gene mutations including in tumour suppressor gene p53 and the MYC proto-oncogene [110]. One study showed that AID was barely detectable in biopsies of normal livers $(n=6)$ but was present in $80 \%$ of cases of PSC $(n=20)$ and $93 \%$ of cases of cholangiocarcinoma $(n=30)$ [110].

Cyclo-Oxygenase-2 (COX-2) is an inflammatory mediator that increases prostaglandin production and is 


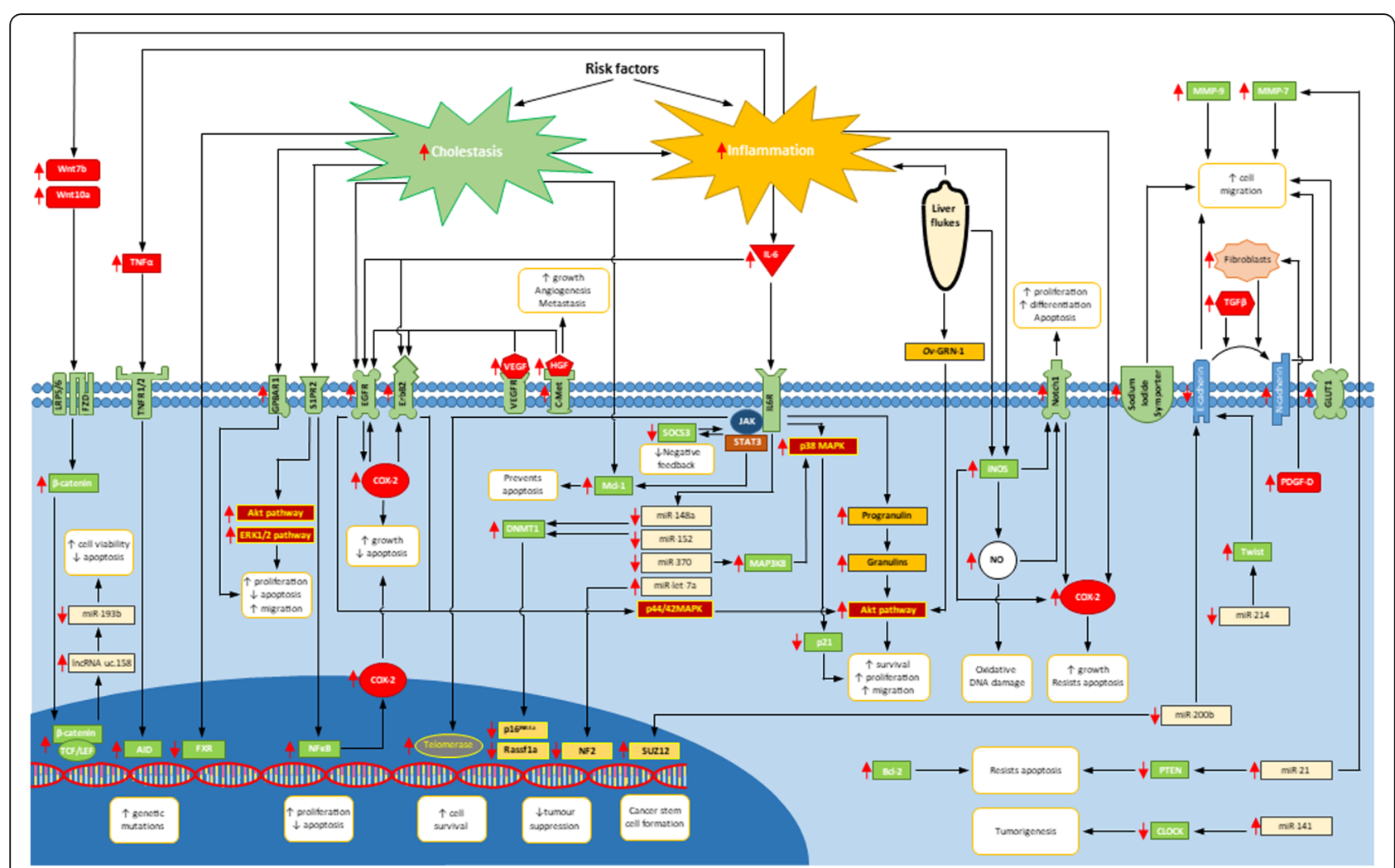

Fig. 1 The molecular pathogenesis of cholangiocarcinoma: The majority of risk factors for cholangiocarcinoma cause chronic inflammation and/or cholestasis. Inflammatory mediators such as IL-6 and TNFa activate a number of pathways such as JAK-STAT, p38 MAPK and Akt resulting in increased cell growth, survival and proliferation. Macrophages secrete ligands that activate the Wnt/ $\beta$-catenin pathway, leading to TCF/LEFmediated gene transcription. Although cholestasis causes inflammation, prolonged exposure of bile acids can have direct cellular effects leading to upregulation of COX-2 and Mcl-1 resulting in resistance to apoptosis. Liver flukes can also have direct effects on cholangiocytes via activation of the Akt pathway and upregulation of iNOS, increasing cell survival and proliferation. A number of microRNAs are up- or downregulated in cholangiocarcinoma. All these alterations lead to well-established oncogenic mechanisms; genetic mutations, increased cell growth, survival, and apoptotic resistance. For a full description of the depicted pathways, please refer to the article text.

known to be raised in tissue samples of PSC and cholangiocarcinoma [99, 111]. High COX-2 levels can stimulate growth in cholangiocarcinoma, and COX-2 inhibitors can induce apoptosis and inhibit proliferation by decreasing Akt pathway stimulation and activating p21 and other cyclin-dependent kinase inhibitors [112, 113]. COX-2 is partially regulated by inducible nitric oxide synthase (iNOS) which itself is upregulated by inflammatory cytokines. iNOS has been found to be overexpressed in biopsy specimens from patients with advanced (stage III-IV) PSC [114]. The liver fluke $O$. viverrini also expresses iNOS, but the relevance of this has not yet been determined [115]. As well as regulating COX-2, iNOS also increases nitric oxide (NO) production, which results in oxidative DNA damage by affecting DNA repair mechanisms [116]. Both iNOS and NO upregulate Notch1, a transmembrane receptor with a wide variety of functions including cell proliferation, differentiation and apoptosis. Notch1 interacts with COX-2 to make cells more resistant to apoptosis, and has been shown to be upregulated in both intrahepatic and extrahepatic cholangiocarcinoma [117-119].

Recent insights have highlighted the role of macrophages in the activation of the Wnt signalling pathway in cholangiocarcinogenesis. Inflammatory macrophages produce Wnt ligands, which normally have the physiological role of mediating epithelial repair when there is damage to the biliary epithelium [120]. The macrophages upregulate the transcription and production of Wnt7b and Wnt10a, which are excreted and play a paracrine function by binding to the receptor FZD and its co-receptors LRP5/LRP6 on cholangiocytes [120]. Activation of the FZD-LRP5/6 receptor inhibits the intracellular $\beta$-catenin degradation complex, leading to an accumulation of $\beta$-catenin [121]. $\beta$-catenin interacts with the TCF/LEF family of transcription factors in the nucleus, leading to increased cell viability and resistance to apoptosis [122]. 


\section{Cholestasis and bile acids}

Under normal physiological circumstances, conjugated bile acids can act as ligands for the G Protein-Coupled Bile Acid Receptor 1 (GPBAR1) that affects chloride and bicarbonate excretion, cell proliferation and apoptosis of cholangiocytes [123, 124]. Any obstruction of the flow of bile results in cholestasis and an abnormal accumulation of bile acids within the biliary tree. This results in a decrease in $\mathrm{pH}$ leading to enhanced rates of apoptosis [123]. High expression of GPBAR1 has been detected in human-derived samples of cholangiocarcinoma and studies have shown its role as a resistor of apoptosis and promoter of proliferation in cholangiocytes [124, 125]. Conjugated bile acids can also act as ligands for the S1PR2 receptor, leading to activation of the ERK1/2, Akt and Nuclear Factor-Kappa B (NF- $\kappa$ B) pathways resulting in increased COX-2, cell proliferation, migration and survival [126-128]. Excess intracellular bile acids also decrease expression of the nuclear Farnesoid X Receptor (FXR) [129]. Activation of FXR normally results in the excretion of bile acids, and a reduction in FXR causes an intracellular accumulation of bile acids [130]. The bile acid deoxycholic acid increases the survival of Mcl-1 that promotes proliferation, which may be one mechanism by which increased intracellular bile acids promote cell survival [29]. Other specific bile acids (e.g. taurocholic acid) are known to stimulate cholangiocyte proliferation [131], and the bile salt glycochenodeoxycholate has been shown to cause oxidative stress to cholangiocytes and cause subsequent genetic alterations [132]. Conjugated bile acids also activate EGFR leading to increased COX-2 expression and activation of the p38 MAPK and p44/42 MAPK pathways [123, 133], and oxysterols (oxidised cholesterol derivatives found in higher concentrations in cholestatic bile) have also been shown to increase COX-2 mRNA in cholangiocytes [133].

\section{MicroRNA changes}

MicroRNAs (miRNAs) are small non-coding RNA sequences that regulate post-transcriptional gene expression. Multiple miRNAs are upregulated or downregulated in cholangiocarcinoma leading to mitosis, increased cell survival and metastasis [134]. However, many of the studies investigating miRNA expression in cholangiocarcinoma compare cholangiocarcinoma cells with controls, which make it difficult to discern if changes in miRNA expression are part of the process of carcinogenesis or the sequelae of established cholangiocarcinoma [135]. IL-6 has a direct effect on the expression of some miRNAs, and as chronic inflammation likely precedes cholangiocarcinoma, these miRNAs are more likely to be drivers of carcinogenesis. IL-6 increases expression of miR-let-7a, resulting in decreased expression of the tumour suppressor gene NF2 and subsequent STAT3 activation [136]. It also downregulates miR-148a and miR-152 resulting in increased DNMT1 activity leading to methylation of the tumour suppressor genes $\mathrm{p} 16^{\mathrm{INK} 4 \mathrm{a}}$ and Rassf1a [102]. miR-370 is also downregulated by IL-6, leading to increased expression of the oncogene MAP3K8 [137].

The aforementioned upregulation of the Wnt/ $\beta$-catenin pathway due to the production of Wnt ligands by inflammatory macrophages leads to TCF/LEF gene transcription. This is associated with an increased expression of the long non-coding (lnc) RNA sequence lncRNA uc.158 [122]. lncRNAs, like miRNAs, regulate post-transcriptional gene expression and can also interact with miRNAs [135]. IncRNA uc.158 appears to competitively inhibit miR-193b, which normally has a pro-apoptotic role [122]. This mechanism could explain one of the ways in which activation of the Wnt/ $\beta$-catenin pathway leads to a reduction in apoptosis.

Many other miRNAs are up- or downregulated in in cholangiocarcinoma, although whether or not many of them are the cause or symptom of cholangiocarcinogenesis remains undetermined. Some example miRNA changes include:

- Decreased miR-200b, leading to an increase oncogene Suz12 and a reduction in E-cadherin expression resulting in cancer stem cell generation and cell migration [138, 139];

- Increased miR-141, decreasing expression of CLOCK, a transcription factor associated with circadian rhythm dysfunction and a number of other malignancies [137, 140, 141];

- Decreased miR-214, leading to increased expression of the transcription factor Twist, reducing Ecadherin levels and subsequent cell migration [142]; and

- Increased miR-21, leading to decreased expression of the tumour suppressor gene PTEN that results in resistance to apoptotic signals [143].

For a more comprehensive review of micro- and other non-coding RNA changes associated with cholangiocarcinoma, see recent reviews by Wangyang et al. (2018) [135] and O'Rourke et al. (2018) [134].

\section{Other factors affecting spread and invasion}

A complex interplay exists between increased levels of extracellular ligands, overexpression of membrane-bound transporters and receptors, and dysregulation of intracellular pathways promoting cell survival and proliferation. Like miRNA changes, it is difficult to say if some of the following observations are a cause or symptom of carcinogenesis due to the design of the experiments that have identified these changes. 
The increased levels of cytokine Transforming Growth Factor- $\beta$ (TGF- $\beta$ ) seen in cholangiocarcinoma causes E-cadherin (a cell-cell adhesion molecule) to switch to $\mathrm{N}$-cadherin resulting in loss of adhesion and an ability to invade [144, 145]. Vascular Endothelial Growth Factor (VEGF), a signal protein key in angiogenesis, is high in both cholangiocarcinoma cell lines and tissue samples in vitro [146]. There is evidence that increased VEGF production is driven in part by oestrogens; cholangiocarcinoma cells express oestrogen receptors, can be stimulated to proliferate with $17-\beta$ oestradiol, and can have the stimulatory effect of $17-\beta$ oestradiol halted with oestrogen receptor antagonists such as tamoxifen [94, 147, 148]. The cell surface receptor tyrosine kinase c-Met, usually only present in progenitor and stem cells for the purpose of organogenesis and wound healing, is abnormally high in cholangiocarcinoma along with its only known ligand Hepatocyte Growth Factor (HGF) leading to tumour growth, angiogenesis and metastasis [149, 150]. VEGF, c-Met, IL-6 and COX-2 all interact with the ErbB receptor kinase family leading to activation of p42/44MAPK (via EGFR and ErB2) and the Akt pathway (via ErB2-driven PI3K activation) [151]. Bcl-2, a potent anti-apoptotic protein, has also been found in high levels in cholangiocarcinoma cell lines [152]. The Sodium Iodide Symporter (NIS), more commonly known for its role in iodide uptake in thyroid follicular cells, is significantly upregulated in cholangiocarcinoma and there is evidence that this leads to increased cell migration and invasion [153, 154]. Increased GLUT-1, a glucose transporter commonly found in several cancers due to increased hypoxia from elevated cell metabolism, is associated with poorer cell differentiation and increased migration and metastasis [155].

Significant stromal changes are also seen in cholangiocarcinoma. Cancer-Associated Fibroblasts (CAFs) in the surrounding stroma produce various factors that promote survival, invasion and metastasis via E- to $\mathrm{N}$-cadherin switching, PI3K-Akt pathway activation and other currently unknown mechanisms [99]. In vitro and murine xenograft experiments showed that CAFs express Platelet Derived Growth Factor Receptor $\beta$ (PDGFR- $\beta$ ), and that cultured cholangiocarcinoma cells secrete the PDGFR- $\beta$ ligand Platelet Derived Growth Factor-D (PDGF-D) resulting in fibroblast migration and recruitment [156]. Selective blocking of PDGF-D (produced from cholangiocytes) and Rho GTPases (downstream effectors of PDGFR- $\beta$ activation in CAFs) resulted in reduced CAF migration, supporting this observation. Higher levels of the matrix metalloproteinases MMP-7 and MMP-9 have been observed, resulting in increased extracellular matrix breakdown allowing cells to migrate [157, 158]. Interestingly, the upregulation of MMP-7 appears to be secondary (at least in part) to increased expression of the microRNA miR-21 [158]. Macrophages, whilst playing a role in carcinogenesis through $\mathrm{Wnt} / \beta$-catenin pathway activation, also appear to play a key role in tumour progression in established cholangiocarcinoma. Cancer stem cells located towards the periphery of the primary tumour appear to secrete a number of molecules (e.g. Interleukin-13, -34 and oesteoactivin) that recruit monocytes and cause them to differentiate into Tumour-Associated Macrophages (TAMs) [159]. A high density of TAMs is associated with tumour invasion, metastasis and worse patient outcomes, suggesting that they are used to create a tumour microenvironment that favours tumour progression $[5,159]$.

\section{Genetic and chromosomal factors}

Table 2 summarises genetic mutations and polymorphisms associated with cholangiocarcinoma $[6,24,99$, 109, 160-171]. Only a few studies have reported on chromosomal abnormalities in cholangiocarcinoma and the results have been hard to interpret due to the small number of samples and wide genetic variation between the studied population groups. Evidence for gains at 1q, $7 \mathrm{p}, 8 \mathrm{q}, 17 \mathrm{q}$, and/or 20q and losses at 1p, 3p, 4q, 6q, 8p, 9pq, 13q, 14q, 17p, 18q and/or 21q have been implicated $[162,172]$. Interestingly, genetic variability in cells other than cholangiocytes can be associated with cholangiocarcinoma. For example, Natural killer cells and T-lymphocytes express the receptor NKG2D that plays a role in cell-mediated cytotoxicity and tumour surveillance [161]. One study found that the risk of developing cholangiocarcinoma in patients with PSC varied significantly depending on the NKG2D alleles carried by the patient; some were protective and others more than doubled the risk [173].

\section{Discussion}

Even when diagnosed at an early stage, cholangiocarcinoma is an aggressive malignancy with poor patient outcomes. To reduce global mortality from cholangiocarcinoma, efforts must be multifaceted and focus on prevention, early identification of high-risk individuals and prompt diagnosis as well as molecular-based targeted therapies for established disease. Large-scale population studies have provided insight into a number of preventable and modifiable risk factors that could significantly influence disease incidence. The early identification of patients with chronic infections associated with cholangiocarcinoma (e.g. liver fluke infection and typhoid) can allow for early initiation of antibacterial/antiparasitic treatment with a high chance of cure. Although a treatment to eradicate chronic hepatitis B remains elusive, new treatments for hepatitis $C$ can cure many patients [174]. Whilst lifelong 
Table 2 Genetic mutations and polymorphisms associated with cholangiocarcinoma

\begin{tabular}{|c|c|c|c|c|}
\hline $\begin{array}{l}\text { Gene } \\
\text { abbreviation }\end{array}$ & Gene name & $\begin{array}{l}\text { Protein } \\
\text { abbreviation }\end{array}$ & Protein name & Normal function(s) ${ }^{a}$ \\
\hline \multicolumn{5}{|c|}{ Congenital mutations/polymorphisms } \\
\hline ABCB4 & $\begin{array}{l}\text { ATP Binding Cassette } \\
\text { Subfamily B Member } 4\end{array}$ & MDR3 & Multidrug resistance protein 3 & $\begin{array}{l}\text { Transport of lipids from } \\
\text { hepatocytes to bile }\end{array}$ \\
\hline ABCB11 & $\begin{array}{l}\text { ATP Binding Cassette } \\
\text { Subfamily B Member } 11\end{array}$ & BSEP & Bile Salt Exporter Pump & $\begin{array}{l}\text { Transport of cholate } \\
\text { conjugates from hepatocytes } \\
\text { to bile }\end{array}$ \\
\hline$A B C C 2$ & $\begin{array}{l}\text { ATP Binding Cassette } \\
\text { Subfamily C Member } 2\end{array}$ & MRP2 & Multidrug resistance-associated protein 2 & $\begin{array}{l}\text { Transport of endogenous and } \\
\text { xenobiotic compounds from } \\
\text { hepatocytes to bile }\end{array}$ \\
\hline ATP8B1 & $\begin{array}{l}\text { ATPase Phospholipid } \\
\text { Transporting 8B1 }\end{array}$ & $\mathrm{FIC1}$ & Familial Intrahepatic Cholestasis type 1 & $\begin{array}{l}\text { Transmembrane phospholipid } \\
\text { transfer }\end{array}$ \\
\hline $\operatorname{cox}-2$ & Cyclooxygenase 2 & $\operatorname{cox}-2$ & Cyclooxygenase 2 & Inflammatory cytokine \\
\hline CYP1A2 & Cytochrome P450 1A2 & CYP1A2 & Cytochrome P450 1A2 & Xenobiotic metabolism \\
\hline GST01 & $\begin{array}{l}\text { Glutathione S-transferase } \\
\text { omega-1 }\end{array}$ & GST01 & Glutathione S-transferase omega-1 & $\begin{array}{l}\text { Detoxification of endogenous } \\
\text { and xenobiotic compounds }\end{array}$ \\
\hline KLRK1 & $\begin{array}{l}\text { Killer Cell Lectin Like } \\
\text { Receptor K1 }\end{array}$ & NKG2D & $\begin{array}{l}\text { NKG2-D type II integral membrane } \\
\text { protein }\end{array}$ & Tumour surveillance \\
\hline MTHFR & $\begin{array}{l}\text { Methylenetetrahydrofolate } \\
\text { Reductase }\end{array}$ & MTHFR & $\begin{array}{l}\text { 5,10-Methylenetetrahydrofolate } \\
\text { reductase }\end{array}$ & DNA methylation \\
\hline NAT2 & N-Acetyltransferase 2 & ARY2 & Arylamine $\mathrm{N}$-acetyltransferase 2 & $\begin{array}{l}\text { Drug and carcinogen } \\
\text { metabolism }\end{array}$ \\
\hline $\mathrm{NR} 1 \mathrm{H} 4$ & $\begin{array}{l}\text { Nuclear Receptor Subfamily } 1 \\
\text { Group H Member } 4\end{array}$ & BAR (FXR) & Bile acid receptor (Farnesoid $\mathrm{X}$ receptor) & $\begin{array}{l}\text { Negative feedback inhibitor } \\
\text { of bile acid synthesis }\end{array}$ \\
\hline TYMS & Thymidylate Synthetase & TYMS & Thymidylate synthase & DNA repair \\
\hline XRCC1 & $\begin{array}{l}\text { X-Ray Repair Complementing } \\
\text { Defective Repair In Chinese } \\
\text { Hamster Cells } 1\end{array}$ & $\mathrm{XRCC1}$ & DNA repair protein $\mathrm{XRCC1}$ & DNA repair \\
\hline \multicolumn{5}{|c|}{ Acquired mutations } \\
\hline APC & Adenomatous polyposis coli & APC & Adenomatous polyposis coli & Tumour suppressor \\
\hline ARID1A & $\begin{array}{l}\text { AT-Rich Interaction Domain } \\
1 \mathrm{~A}\end{array}$ & ARID1a & $\begin{array}{l}\text { AT-rich interactive domain-containing } \\
\text { protein } 1 \mathrm{~A}\end{array}$ & Transcription factor \\
\hline AXIN1 & AXIN1 & Axin-1 & Axis inhibitor protein 1 & Regulates apoptosis \\
\hline BAP1 & BRCA1 Associated Protein 1 & BAP1 & $\begin{array}{l}\text { Ubiquitin carboxyl-terminal hydrolase } \\
\text { BAP1 }\end{array}$ & Regulates cell growth \\
\hline $\mathrm{BCL}-2$ & B cell Lymphoma-2 & $\mathrm{BCl}-2$ & B-cell lymphoma 2 & Regulates apoptosis \\
\hline \multirow[t]{2}{*}{ BCL2L1 } & \multirow[t]{2}{*}{ B Cell Lymphoma Like 1} & $\mathrm{BCl}-\mathrm{xL}^{\mathrm{b}}$ & B-cell lymphoma-extra large & Inhibits apoptosis \\
\hline & & $\mathrm{BCl}-x S^{b}$ & B-cell lymphoma-extra small & Promotes apoptosis \\
\hline BRAF & $\begin{array}{l}\text { B Rapidly Accelerated } \\
\text { Fibrosarcoma }\end{array}$ & B-Raf & B-Rapidly Accelerated Fibrosarcoma & Proto-oncogene \\
\hline BRCA1 & Breast Cancer 1 & BRCA1 & $\begin{array}{l}\text { Breast cancer type } 1 \text { susceptibility } \\
\text { protein }\end{array}$ & $\begin{array}{l}\text { Tumour suppressor and } \\
\text { DNA repair }\end{array}$ \\
\hline BRCA2 & Breast Cancer 2 & BRCA2 & Breast cancer type 2 susceptibility protein & DNA repair \\
\hline CCND1 & Cyclin D1 & CCND1 & G1/S-specific cyclin-D1 & Regulates cell growth \\
\hline $\mathrm{CDH} 1$ & Cadherin 1 & E-cadherin & Epithelial cadherin & $\begin{array}{l}\text { Tumour suppressor, } \\
\text { cell adhesion }\end{array}$ \\
\hline CDK6 & Cyclin-Dependent Kinase 6 & CDK6 & Cyclin-Dependent Kinase 6 & $\begin{array}{l}\text { Controls cell cycle and } \\
\text { differentiation }\end{array}$ \\
\hline \multirow[t]{2}{*}{ CDKN2A } & \multirow{2}{*}{$\begin{array}{l}\text { Cyclin-Dependent Kinase } \\
\text { Inhibitor } 2 \mathrm{~A}\end{array}$} & $\mathrm{p} 16^{\mathrm{b}}$ & Protein 16 & Tumour suppressor \\
\hline & & p14arf ${ }^{b}$ & Protein 14 Alternate Reading Frame & Tumour suppressor \\
\hline CTNNB1 & Catenin Beta 1 & B-catenin & B-catenin & Proto-oncogene \\
\hline $\begin{array}{l}\text { EGFR } \\
\text { (ERBB1) }\end{array}$ & $\begin{array}{l}\text { Epidermal Growth Factor } \\
\text { Receptor }\end{array}$ & EGFR (ErbB-1) & Epidermal Growth Factor Receptor & Proto-oncogene \\
\hline ERBB2 & Avian Erythroblastosis oncogene B2 & ErbB-2 (HER2) & Receptor tyrosine-protein kinase & Proto-oncogene \\
\hline
\end{tabular}


Table 2 Genetic mutations and polymorphisms associated with cholangiocarcinoma (Continued)

\begin{tabular}{|c|c|c|c|c|}
\hline $\begin{array}{l}\text { Gene } \\
\text { abbreviation }\end{array}$ & Gene name & $\begin{array}{l}\text { Protein } \\
\text { abbreviation }\end{array}$ & Protein name & Normal function $(s)^{a}$ \\
\hline (HER2) & & & erbB-2 & \\
\hline FBXW7 & $\begin{array}{l}\text { F-Box And WD Repeat } \\
\text { Domain Containing } 7\end{array}$ & FBXW7 & $\begin{array}{l}\text { F-box/WD repeat-containing } \\
\text { protein } 7\end{array}$ & $\begin{array}{l}\text { Component of proteasomal } \\
\text { protein degradation pathway }\end{array}$ \\
\hline FGF19 & Fibroblast Growth Factor 19 & FGF19 & Fibroblast Growth Factor 19 & $\begin{array}{l}\text { Regulation of bile salt } \\
\text { synthesis }\end{array}$ \\
\hline FGFR2 & $\begin{array}{l}\text { Fibroblast Growth Factor } \\
\text { Receptor } 2\end{array}$ & FGFR2 & $\begin{array}{l}\text { Fibroblast Growth Factor } \\
\text { Receptor } 2\end{array}$ & $\begin{array}{l}\text { Cell surface receptor } \\
\text { regulating cell proliferation, } \\
\text { differentiation, migration } \\
\text { and apoptosis }\end{array}$ \\
\hline IDH1 & Isocitrate dehydrogenase 1 & $\begin{array}{l}\text { Isocitrate de- } \\
\text { hydrogenase } 1\end{array}$ & $\begin{array}{l}\text { Isocitrate dehydrogenase } \\
\text { (cytoplasmic) }\end{array}$ & $\begin{array}{l}\text { Glucose metabolism, indirectly } \\
\text { mitigates oxidative stress }\end{array}$ \\
\hline $\mathrm{IDH} 2$ & Isocitrate dehydrogenase 2 & $\begin{array}{l}\text { Isocitrate de- } \\
\text { hydrogenase } 2\end{array}$ & $\begin{array}{l}\text { Isocitrate dehydrogenase } \\
\text { (mitochondrial) }\end{array}$ & $\begin{array}{l}\text { Glucose metabolism, indirectly } \\
\text { mitigates oxidative stress }\end{array}$ \\
\hline Keap1 & $\begin{array}{l}\text { Kelch-like ECH-associated } \\
\text { protein } 1\end{array}$ & KEAP1 & Kelch-like ECH-associated protein 1 & $\begin{array}{l}\text { Prevents Nrf2-driven } \\
\text { transcription }\end{array}$ \\
\hline KRAS & Kirsten Rat Sarcoma & K-Ras & Kirsten Rat Sarcoma & Proto-oncogene \\
\hline LTO1 & $\begin{array}{l}\text { LTO1, ABCE1 maturation } \\
\text { factor }\end{array}$ & LTO1 & Protein LTO1 homolog & Ribosome biogenesis \\
\hline MCL-1 & Myeloid Cell Leukaemia 1 & $\begin{array}{l}\text { Mcl-1 (3 } \\
\text { isoforms) }\end{array}$ & $\begin{array}{l}\text { Induced myeloid leukaemia cell differentiation } \\
\text { protein Mcl-1 }\end{array}$ & $\begin{array}{l}\text { Isoform } 1 \text { resists apoptosis, } \\
\text { isoforms } 2 \text { \& } 3 \text { promote } \\
\text { apoptosis }\end{array}$ \\
\hline MDM2 & Mouse Double Minute 2 & Mdm2 & E3 ubiquitin-protein ligase Mdm2 & Proto-oncogene, p53 inhibitor \\
\hline MYC & $\begin{array}{l}\text { Avian myelocytomatosis } \\
\text { virus oncogene cellular } \\
\text { homolog }\end{array}$ & Myc & Myc proto-oncogene protein & Proto-oncogene \\
\hline NF1 & Neurofibromin 1 & NF1 & Neurofibromin & Stimulates Ras activity \\
\hline PBRM1 & Polybromo 1 & PBRM1 & Protein polybromo-1 & $\begin{array}{l}\text { Negative regulator of cell } \\
\text { proliferation }\end{array}$ \\
\hline PIK3CA & $\begin{array}{l}\text { Phosphatidylinositol-4,5- } \\
\text { Bisphosphate 3-Kinase } \\
\text { Catalytic Subunit Alpha }\end{array}$ & PIK3CA & $\begin{array}{l}\text { Phosphatidylinositol 4,5-bisphosphate } \\
\text { 3-kinase catalytic subunit alpha isoform }\end{array}$ & $\begin{array}{l}\text { Generates PIP3 that activates } \\
\text { signalling cascades for cell } \\
\text { growth, survival and motility }\end{array}$ \\
\hline PRSS1 & Protease, Serine 1 & TRY1 & Trypsin-1 & Serine protease \\
\hline PRSS2 & Protease, Serine 2 & TRY2 & Trypsin-2 & Serine protease \\
\hline PTEN & $\begin{array}{l}\text { Phosphatase And Tensin } \\
\text { Homolog }\end{array}$ & PTEN & $\begin{array}{l}\text { Phosphatidylinositol 3,4,5-trisphosphate } \\
\text { 3-phosphatase and dual-specificity } \\
\text { protein phosphatase PTEN }\end{array}$ & Tumour suppressor \\
\hline RAD51AP1 & RAD51 Associated Protein 1 & RAD51AP1 & RAD51 Associated Protein 1 & DNA damage repair \\
\hline RASSF1A & $\begin{array}{l}\text { Ras association domain } \\
\text { family } 1 \text { isoform A }\end{array}$ & RASSF1A & $\begin{array}{l}\text { Ras association domain-containing } \\
\text { protein } 1 \text { isoform A }\end{array}$ & Tumour suppressor \\
\hline ROS1 & $\begin{array}{l}\text { Reactive Oxygen Species } \\
\text { Proto-Oncogene 1, Receptor Tyrosine Kinase }\end{array}$ & ROS1 & $\begin{array}{l}\text { Proto-oncogene tyrosine-protein } \\
\text { kinase ROS }\end{array}$ & $\begin{array}{l}\text { Epithelial cell differentiation, } \\
\text { activation of signal pathways } \\
\text { of cell differentiation, } \\
\text { proliferation, growth } \\
\text { and survival }\end{array}$ \\
\hline SMAD4 & $\begin{array}{l}\text { Small Mothers Against } \\
\text { Decapentaplegic } 4\end{array}$ & SMAD4 & $\begin{array}{l}\text { Small Mothers Against Decapentaplegic } \\
4\end{array}$ & $\begin{array}{l}\text { Tumour suppressor, } \\
\text { transcription factor }\end{array}$ \\
\hline SOCS3 & $\begin{array}{l}\text { Suppressor Of Cytokine } \\
\text { Signaling } 3\end{array}$ & SOCS3 & Suppressor Of Cytokine Signaling 3 & Signal transduction inhibitor \\
\hline TP53 & Tumour Protein 53 & p53 & Protein 53 & Tumour suppressor \\
\hline
\end{tabular}

Relevant to cholangiocarcinoma development. ${ }^{\text {b}}$ Through alternate splicing

treatment can suppress viral replication and prevent cirrhosis, unfortunately access to medication continues to be limited; less than $2 \%$ of people with hepatitis B worldwide are on treatment [175]. Global public health initiatives to provide access to medication for hepatitis $B$ and $\mathrm{C}$, and a focus on the modifiable lifestyle factors of alcohol, smoking, and obesity, would have a profound effect on a number of patient outcomes including 
cholangiocarcinoma incidence. With a global prevalence of $25 \%$, the recent identification of NAFLD as a greater risk factor for cholangiocarcinoma than obesity or diabetes is significant and likely to pose an increasing health burden [176]. Screening patients with PSC for cholangiocarcinoma with regular non-invasive imaging and the tumour marker Carbohydrate Antigen 19-9 (CA 19-9) is done by many centres, although evidence of efficacy of this approach is lacking [177].

As many of the risk factors above cannot be fully eradicated, and the majority of cases of cholangiocarcinoma occur sporadically, an understanding of the molecular pathogenesis of cholangiocarcinoma can allow for the identification of potential early diagnostic biomarkers. For established cholangiocarcinoma, many potential therapeutic targets have been identified in recent years. Drugs have been developed that can target cell surface receptors, their ligands or their intracellular tyrosine kinase components. Example therapies and their respective targets include $[160,178]$ :

- Intracellular receptor tyrosine kinase blockade by lapatinib (ErbB2), erlotinib and vandetanib (EGFR), sunitinib and cediranib (VEGFR, PDGFR) and ponatinib (Fibroblast Growth Factor Receptor 2 (FGFR2));

- Extracellular antibody blockade by cetuximab and panitumumab (EGFR), brontictuzumab (Notch1) and vanctitumab (FZD7);

- Ligand blockade by bevacizumab (VEGF) and demcizumab (DLL4, the ligand of Notch1) [179].

As many of these receptors have common downstream effectors, other therapeutics have been developed to target their shared intracellular pathways. Both the MAPK/ ERK and Akt pathways are activated by the downstream sequelae of cholestasis and inflammation (Fig. 1). Sorafenib, as well as acting as a tyrosine kinase inhibitor on a number of tyrosine kinases including VEGFR-2 and PDGFR, blocks the MAPK/ERK pathway [180]. mTOR, a downstream effector of the Akt pathway, can be targeted using the mTOR kinase inhibitor everolimus [160]. Unfortunately, results from targeted therapies to date have been disappointing. Targeting of EGFR and its downstream pathways by cetuximab, panitumumab and erlotinib has failed to show significant survival benefits in clinical trials [181-183]. A similar lack of response has been observed when targeting VEGF and its downstream pathways by sorafenib or cediranib $[184,185]$. As a result, current guidelines only support the use of targeted therapies in the context of clinical trials [186]. Promising future targets include Fibroblast Growth Factor Receptor 2 (FGFR2), Isocitrate Dehydrogenase 1 and 2 (IDH1/2) and Programmed Death Ligand 1 (PD-L1) [8].
Whilst the above results seem discouraging, a significant confounding factor is that many of the earlier trials did not perform molecular profiling of enrolled patients to assess whether or not the target was present in all participants. Future research on targeted therapies will benefit from the wider use of more appropriate study designs, such as basket and umbrella trials.

\section{Conclusion}

Many risk factors have been implicated in cholangiocarcinogenesis, but the evidence supporting each factor is often limited to population-based studies with the inherit limitations of such study designs. Although these risk factors are variable in cause and nature, the majority of them have a common theme of causing chronic inflammation and cholestasis leading to a series of molecular changes that result in reactive cell proliferation, genetic/epigenetic mutations and cancer development. An understanding of the molecular pathogenesis of cholangiocarcinoma is vital when developing new diagnostic biomarkers and targeted therapies to tackle this disease.

\section{Abbreviations}

AID: Activation-Induced cytidine Deaminase; AIDS: Acquired Immune Deficiency Syndrome; AUC: Area Under the Curve; CA 19-9: Carbohydrate Antigen 19-9; CAF: Cancer-Associated Fibroblasts; Cl: Confidence Interval; COX-2: Cyclo-Oxygenase-2; DNA: Deoxyribonucleic Acid; ECC: Extrahepatic Cholangiocarcinoma; EGFR: Epidermal Growth Factor Receptor; FGFR2: Fibroblast Growth Factor Receptor 2; FPLD: Fibropolycystic Liver Disease; FXR: Farnesoid X Receptor; GPBAR1: G Protein-Coupled Bile Acid Receptor 1; HGF: Hepatocyte Growth Factor; HIV: Human Immunodeficiency Virus; IBD: Inflammatory Bowel Disease; ICC: Intrahepatic Cholangiocarcinoma; IDH: Isocitrate Dehydrogenase; IGF-1: Insulin-like Growth Factor-1; IGF-1R: Insulin-like Growth Factor-1 Receptor; IL6: Interleukin-6; iNOS: inducible Nitric Oxide Synthase; IPNB: Intraductal Papillary Neoplasm of the Bile duct; IncRNA: long non-coding RNA; miRNA: micro Ribonucleic Acid; MMP: Matrix Metalloproteinase; MMR: Mismatch Repair; NAFL: Non-Alcoholic Fatty Liver; NAFLD: NonAlcoholic Fatty Liver Disease; NASH : Non-Alcoholic Steatohepatitis; NFKB: Nuclear Factor-Kappa B; NIS: Sodium lodide Symporter; NO: Nitric Oxide; OR: Odds Ratio; PDGF-D: Platelet Derived Growth Factor-D; PDGFR- $\beta$ : Platelet Derived Growth Factor Receptor- $\beta$; PSC: Primary Sclerosing Cholangitis; ROC: Receiver Operating Characteristic; RPC: Recurrent Pyogenic Cholangitis; SEER: Surveillance, Epidemiology, and End Results; TAM: Tumour-Associated Macrophages; TGF- $\beta$ : Transforming Growth Factor- $\beta$; TNF- $\alpha$ : Tumour Necrosis Factor-a; VEGF: Vascular Endothelial Growth Factor; VEGFR: Vascular Endothelial Growth Factor Receptor

\section{Acknowledgements}

None to declare.

\section{Funding}

PLL's postgraduate studies are part-funded by the Limoges Charitable Trust (charity no: 1016178). SPP is supported by the National Institute for Health Research University College London Hospitals Biomedical Research Centre. This funding provided financial assistance for the time dedicated to writing the manuscript.

\section{Availability of data and materials \\ Not applicable.}

\section{Authors' contributions}

PLL and GG wrote the manuscript and SPP provided senior critical revision. All authors gave final approval of the version to be published and agree to be accountable for all aspects of the work. 
Ethics approval and consent to participate

Not applicable.

\section{Consent for publication}

Not applicable.

\section{Competing interests}

The authors declare that they have no competing interests.

\section{Publisher's Note}

Springer Nature remains neutral with regard to jurisdictional claims in published maps and institutional affiliations.

Received: 15 November 2018 Accepted: 20 February 2019 Published online: 28 February 2019

\section{References}

1. Bragazzi MC, Ridola L, Safarikia S, Matteo SD, Costantini D, Nevi L, et al. New insights into cholangiocarcinoma: multiple stems and related cell lineages of origin. Ann Gastroenterol. 2018;31:42-55.

2. Razumilaza N, Gores G. Cholangiocarcinoma. Lancet. 2014;383:21/27.

3. Cardinale V, Carpino G, Reid L, Gaudio E, Alvaro D. Multiple cells of origin in cholangiocarcinoma underlie biological, epidemiological and clinical heterogeneity. World J Gastrointest Oncol. 2012;4:94-102.

4. Patel T. New insights into the molecular pathogenesis of intrahepatic cholangiocarcinoma. J Gastroenterol. 2014:49:165-72.

5. Banales J, Cardinale V, Carpino G, Marzioni M, Andersen J, Invernizzi P, et al. Expert consensus document: Cholangiocarcinoma: current knowledge and future perspectives consensus statement from the European Network for the Study of Cholangiocarcinoma (ENS-CCA). Nat Rev Gastroenterol Hepatol. 2016;13:261-80.

6. Bridgewater J, Galle P, Khan S, Llovet J, Park J, Patel T, et al. Guidelines for the diagnosis and management of intrahepatic cholangiocarcinoma. Hepatol. 2014;60:1268-89.

7. Kilander C, Mattsson F, Ljung R, Lagergren J, Sadr-Azodi O. Systematic underreporting of the population-based incidence of pancreatic and biliary tract cancers. Acta Oncol. 2014:53:822-9.

8. Rizvi S, Khan SA, Hallemeier CL, Kelley RK, Gores GJ. Cholangiocarcinoma evolving concepts and therapeutic strategies. Nat Rev Clin Oncol. 2018;15: 95-111.

9. Schlitter AM, Born D, Bettstetter M, Specht K, Kim-Fuchs C, Riener M-O, et al. Intraductal papillary neoplasms of the bile duct: stepwise progression to carcinoma involves common molecular pathways. Mod Pathol. 2013;27:73.

10. Sato Y, Sasaki M, Harada K, Aishima S, Fukusato T, Ojima H, et al. Pathological diagnosis of flat epithelial lesions of the biliary tract with emphasis on biliary intraepithelial neoplasia. J Gastroenterol. 2014;49:64-72.

11. Bagante F, Gamblin TC, Pawlik TM. Cholangiocarcinoma risk factors and the potential role of aspirin: Bagante et al. Hepatology. 2016;64:708-10.

12. Petrick JL, Thistle JE, Zeleniuch-Jacquotte A, Zhang X, Wactawski-Wende J, Van Dyke AL, et al. Body Mass Index, Diabetes and Intrahepatic Cholangiocarcinoma Risk: The Liver Cancer Pooling Project and Metaanalysis. Am J Gastroenterol. 2018;113:1494-505.

13. Plentz RR, Malek NP. Clinical presentation, risk factors and staging systems of cholangiocarcinoma. Best Pract Res Clin Gastroenterol. 2015;29:245-52.

14. Rupp C, Bode KA, Chahoud F, Wannhoff A, Friedrich K, Weiss K-H, et al. Risk factors and outcome in patients with primary sclerosing cholangitis with persistent biliary candidiasis. BMC Infect Dis. 2014;14.

15. Gupta A, Dixon E. Epidemiology and risk factors: intrahepatic cholangiocarcinoma. HepatoBiliary Surg Nutr. 2017;6:101-4.

16. Ghouri YA, Mian I, Blechacz B. Cancer review: Cholangiocarcinoma. J Carcinog. 2015;14:1.

17. Cai H, Kong W-T, Chen C-B, Shi G-M, Huang C, Shen Y-H, et al. Cholelithiasis and the risk of intrahepatic cholangiocarcinoma: a meta-analysis of observational studies. BMC Cancer. 2015;15.

18. Ettel M, Eze O, Xu R. Clinical and biological significance of precursor lesions of intrahepatic cholangiocarcinoma. World J Hepatol. 2015;7:2563-70.

19. Welzel T, Mellemkjaer L, Gloria G, Sakoda L, Hsing A, El Ghormli L, et al. Risk factors for intrahepatic cholangiocarcinoma in a low-risk population: a nationwide case-control study. Int J Cancer. 2007;120:638-41.

20. Goral V. Cholangiocarcinoma: New Insights. Asian Pac J Cancer Prev. 2017; 18:1469-73.
21. Al-Sukhni W, Gallinger S, Pratzer A, Wei A, Ho CS, Kortan P, et al. Recurrent Pyogenic Cholangitis with Hepatolithiasis-The Role of Surgical Therapy in North America. J Gastrointest Surg. 2008;12:496-503.

22. Tyson G, El-Serag H. Risk factors for cholangiocarcinoma. Hepatology. 2011; 54:173-84.

23. Cloyd JM, Chun YS, Ikoma N, Vauthey JN, Aloia TA, Cuddy A, et al. Clinical and Genetic Implications of DNA Mismatch Repair Deficiency in Biliary Tract Cancers Associated with Lynch Syndrome. J Gastrointest Cancer. 2018:49:93-6.

24. Wadsworth C, Dixon P, Wong J, Chapman M, McKay S, Sharif A, et al. Genetic factors in the pathogenesis of cholangiocarcinoma. Dig Dis. 2011;29:93-7.

25. Andersen JB. Molecular pathogenesis of intrahepatic cholangiocarcinoma. J Hepato-Biliary-Pancreat Sci. 2015;22:101-13.

26. Lutz H, Trautwein C, Tischendorf J. Primary sclerosing cholangitis - diagnosis and treatment. Dtsch Arztebl Int. 2013;110:867-74.

27. Ehlken H, Zenouzi R, Schramm C. Risk of cholangiocarcinoma in patients with primary sclerosing cholangitis: diagnosis and surveillance. Curr Opin Gastroenterol. 2017;33(2):78-84

28. Boonstra K, Weersma RK, van Erpecum KJ, Rauws EA, Spanier BWM, Poen AC, et al. Population-based epidemiology, malignancy risk, and outcome of primary sclerosing cholangitis: Boonstra et al. Hepatology. 2013;58:2045-55.

29. Werneburg NW, Yoon J-H, Higuchi H, Gores GJ. Bile acids activate EGF receptor via a TGF-a-dependent mechanism in human cholangiocyte cell lines. Am J Physiol-Gastrointest Liver Physiol. 2003;285:G31-6.

30. Hadžić N, Strazzabosco M. Fibropolycystic Liver Diseases and Congenital Biliary Abnormalities. In: Dooley JS, Lok ASF, Garcia-Tsao G, Pinzani M, editors. Sherlock's Diseases of the Liver and Biliary System. Chichester, UK: Wiley 2018. p. 308-327.

31. Carpentier R, Suñer R, van Hul N, Kopp J, Beaudry J, Cordi S, et al. Embryonic ductal plate cells give rise to cholangiocytes, periportal hepatocytes and adult liver progenitor cells. Gastroenterology. 2011;141:1432-8.

32. Khan S, Toledano M, Taylor-Robinson S. Epidemiology, risk factors, and pathogenesis of cholangiocarcinoma. HPB. 2008;10:77-82.

33. Lipsett PA, Pitt HA, Colombani PM, Boitnott JK, Cameron JL. Choledochal cyst disease. A changing pattern of presentation. Ann Surg. 1994;220:644-52.

34. Bhalla A, Mann SA, Chen S, Cummings OW, Lin J. Histopathological evidence of neoplastic progression of von Meyenburg complex to intrahepatic cholangiocarcinoma. Hum Pathol. 2017:67:217-24.

35. Khan S, Thomas H, Davidson B, Taylor-Robinson S. Cholangiocarcinoma. Lancet. 2005;366:1303-14.

36. Squadroni M, Tondulli L, Gatta G, Mosconi S, Beretta G, Labianca R. Cholangiocarcinoma. Crit Rev Oncol Hematol. 2017;116:11-31.

37. McCormick PA, Jalan R. Hepatic Cirrhosis. In: Dooley JS, Lok ASF, Garcia-Tsao G, Pinzani M, editors. Sherlock's Diseases of the Liver and Biliary System. Chichester, UK: Wiley 2018. p. 107-126.

38. Palmer W, Patel T. Are common factors involved in the pathogenesis of primary liver cancers? A metaanalysis of risk factors for intrahepatic cholangiocarcinoma. J Hepatol. 2012;57:69-76.

39. Sirica A. Desmoplastic stroma and cholangiocarcinoma: Clinical implications and therapeutic targeting. Hepatology. 2014;59:2397-402.

40. Petrick JL, Yang B, Altekruse SF, Van Dyke AL, Koshiol J, Graubard Bl, et al. Risk factors for intrahepatic and extrahepatic cholangiocarcinoma in the United States: A population-based study in SEER-Medicare. PLOS ONE. 2017; 12:e0186643.

41. Ridlon JM, Kang DJ, Hylemon PB, Bajaj JS. Bile acids and the gut microbiome. Curr Opin Gastroenterol. 2014;30:332-8.

42. Kakiyama G, Pandak WM, Gillevet PM, Hylemon PB, Heuman DM, Daita K, et al. Modulation of the fecal bile acid profile by gut microbiota in cirrhosis. J Hepatol. 2013;58:949-55.

43. Housset C. Gallstone disease, towards a better understanding and clinical practice. Curr Opin Gastroenterol. 2018;34:57-8.

44. Xiong J, Wang Y, Huang H, Bian J, Wang A, Long J, et al. Systematic review and meta-analysis: cholecystectomy and the risk of cholangiocarcinoma. Oncotarget. 2017:8:59648-57.

45. Pomare EW, Heaton KW. The effect of cholecystectomy on bile salt metabolism. Gut. 1973;14:753-62.

46. Nordenstedt H, Mattsson F, El-Serag H, Lagergren J. Gallstones and cholecystectomy in relation to risk of intra- and extrahepatic cholangiocarcinoma. Br J Cancer. 2012;106:1011-5.

47. Huang M, Chen C, Yen C, Yang J, Yang C, Yeh Y, et al. Relation of hepatolithiasis to helminthic infestation. J Gastroenterol Hepatol. 2005;20:141-6. 
48. Yonem O, Bayraktar Y. Clinical characteristics of Caroli's syndrome. World J Gastroenterol. 2007;13:1934-7.

49. Eslick GD, Shaffer EA. Epidemiology of Gallstones and Biliary Tract Cancers. In: Talley NJ, Locke GR, Moayyedi P, West J, Ford AC, Saito YA, editors. GI Epidemiology. Chichester, UK: Wiley; 2014. p. 296-305.

50. Suzuki Y, Mori T, Abe N, Sugiyama M, Atomi Y. Predictive factors for cholangiocarcinoma associated with hepatolithiasis determined on the basis of Japanese Multicenter study: Cholangiocarcinoma with hepatolithiasis. Hepatol Res. 2012;42:166-70

51. Kim HJ, Kim JS, Joo MK, Lee BJ, Kim JH, Yeon JE, et al. Hepatolithiasis and intrahepatic cholangiocarcinoma: A review. World J Gastroenterol. 2015;21: 13418-31.

52. Sithithaworn P, Yongvanit P, Duenngai K, Kiatsopit N, Pairojkul C. Roles of liver fluke infection as risk factor for cholangiocarcinoma. J Hepato-BiliaryPancreat Sci. 2014;21:301-8.

53. Sripa B, Kaewkes S, Sithithaworn P, Mairiang E, Laha T, Smout M, et al. Liver Fluke Induces Cholangiocarcinoma. PLoS Med. 2007:4:e201.

54. Easterbrook PJ, Roberts T, Sands A, Peeling R. Diagnosis of viral hepatitis. Curr Opin HIV AIDS. 2017;12:302-14

55. Zhou Y, Zhao Y, Li B, Huang J, Wu L, Xu D, et al. Hepatitis viruses infection and risk of intrahepatic cholangiocarcinoma: evidence from a meta-analysis. BMC Cancer. 2012;12:289.

56. Zhang H, Zhu B, Zhang H, Liang J, Zeng W. HBV Infection Status and the Risk of Cholangiocarcinoma in Asia: A Meta-Analysis. BioMed Res Int. 2016; 2016:1-14.

57. Li H, Hu B, Zhou Z-Q, Guan J, Zhang Z-Y, Zhou G-W. Hepatitis C virus infection and the risk of intrahepatic cholangiocarcinoma and extrahepatic cholangiocarcinoma: evidence from a systematic review and meta-analysis of 16 case-control studies. World J Surg Oncol. 2015;13:161.

58. Ralphs $\mathrm{S}$, Khan $\mathrm{S}$. The role of hepatitis viruses in cholangiocarcinoma. J Viral Hepat. 2013;20:297-305.

59. Abdel Wahab M, Mostafa M, Salah T, Fouud A, Kandeel T, Elshobary M, et al. Epidemiology of hilar cholangiocarcinoma in Egypt: single center study. Hepatogastroenterology. 2007:54:1626-31

60. Ray S, Sanyal S, Das K, Ghosh R, Das S, Khamrui S, et al. Outcome of surgery for recurrent pyogenic cholangitis: a single center experience. HPB. 2016;18:821-6.

61. Verweij KE, van Buuren H. Oriental cholangiohepatitis (recurrent pyogenic cholangitis): a case series from the Netherlands and brief review of the literature. Neth J Med. 2016;74:401-5.

62. Jensen BE-O, Oette M, Haes J, Häussinger D. HIV-Associated Gastrointestinal Cancer. Oncol Res Treat. 2017;40:115-8.

63. Shaib Y, El-Serag H, Davila J, Morgan R, McGlynn K. Risk factors of intrahepatic cholangiocarcinoma in the United States: a case-control study. Gastroenterology. 2005;128:620-6.

64. Rojas-Feria M. Hepatobiliary manifestations in inflammatory bowel disease: The gut, the drugs and the liver. World J Gastroenterol. 2013;19:7327.

65. Annese V, Beaugerie L, Egan L, Biancone L, Bolling C, Brandts C, et al. European Evidence-based Consensus: Inflammatory Bowel Disease and Malignancies. J Crohns Colitis. 2015;9:945-65.

66. Taghavi SA, Eshraghian A, Niknam R, Sivandzadeh GR, Bagheri LK. Diagnosis of cholangiocarcinoma in primary sclerosing cholangitis. Expert Rev Gastroenterol Hepatol. 2018;12:575-84.

67. Horsley-Silva JL, Rodriguez EA, Franco DL, Lindor KD. An update on cancer risk and surveillance in primary sclerosing cholangitis. Liver Int. 2017;37:1103-9.

68. Karlsen TH, Boberg KM. Update on primary sclerosing cholangitis. J Hepatol. 2013:59:571-82

69. Chang M, Chang L, Chang HM, Chang F. Intestinal and Extraintestinal Cancers Associated With Inflammatory Bowel Disease. Clin Colorectal Cancer. 2018;17:e29-37.

70. Mima K, Nakagawa S, Sawayama H, Ishimoto T, Imai K, Iwatsuki M, et al. The microbiome and hepatobiliary-pancreatic cancers. Cancer Lett. 2017;402:9-15.

71. Capurso G, Signoretti M, Archibugi L, Stigliano S, Delle FG. Systematic review and meta-analysis: Small intestinal bacterial overgrowth in chronic pancreatitis. United Eur Gastroenterol J. 2016:4:697-705.

72. Shao T, Shao L, Li H, Xie Z, He Z, Wen C. Combined Signature of the Fecal Microbiome and Metabolome in Patients with Gout. Front Microbiol. 2017;8.

73. Lin TY, Shekar AO, Li N, Yeh MW, Saab S, Wilson M, et al. Incidence of abnormal liver biochemical tests in hyperthyroidism. Clin Endocrinol (Oxf). 2017:86:755-9.

74. Zhang Q, Liu S, Guan Y, Chen Q, Zhang Q, Min X. RNASET2, GPR174, and PTPN22 gene polymorphisms are related to the risk of liver damage associated with the hyperthyroidism in patients with Graves' disease. J Clin Lab Anal. 2018;32:e22258.

75. Mancini A, Di Segni C, Raimondo S, Olivieri G, Silvestrini A, Meucci E, et al. Thyroid Hormones, Oxidative Stress, and Inflammation. Mediators Inflamm. 2016;2016:1-12.

76. Pasyechko NV, Kuleshko II, Kulchinska VM, Naumova LV, Smachylo IV, Bob $\mathrm{AO}$, et al. Ultrastructural liver changes in the experimental thyrotoxicosis. Pol J Pathol. 2017:2:144-7.

77. Petrick JL, Campbell PT, Koshiol J, Thistle JE, Andreotti G, Beane-Freeman LE, et al. Tobacco, alcohol use and risk of hepatocellular carcinoma and intrahepatic cholangiocarcinoma: The Liver Cancer Pooling Project. Br J Cancer. 2018;118:1005-12.

78. Bagnardi V, Rota M, Botteri E, Tramacere I, Islami F, Fedirko V, et al. Alcohol consumption and site-specific cancer risk: a comprehensive dose-response meta-analysis. Br J Cancer. 2015;112:580-93.

79. Ye X, Huai J, Ding J, Chen Y, Sun X. Smoking, alcohol consumption, and the risk of extrahepatic cholangiocarcinoma: A meta-analysis. World 」 Gastroenterol. 2013;19:8780-8.

80. Lipshutz G, Brennan T, Warren R. Thorotrast-induced liver neoplasia: a collective review. J Am Coll Surg. 2002;195:713-8.

81. Zhu A, Lauwers G, Tanabe K. Cholangiocarcinoma in association with Thorotrast exposure. J Hepatobiliary Pancreat Surg. 2004;11:430-3.

82. Braconi C, Patel T. Cholangiocarcinoma: New Insights into Disease Pathogenesis and Biology. Infect Dis Clin North Am. 2010;24:871-84.

83. Suk WA, Bhudhisawasdi V, Ruchirawat M. The Curious Case of Cholangiocarcinoma: Opportunities for Environmental Health Scientists to Learn about a Complex Disease. J Environ Public Health. 2018;2018:1-7.

84. Aljiffry M, Abdulelah A, Walsh M, Peltekian K, Alwayn I, Molinari M. EvidenceBased Approach to Cholangiocarcinoma: A Systematic Review of the Current Literature. J Am Coll Surg. 2009;208:134-47.

85. Li J, Han T, Xu L, Luan X. Diabetes mellitus and the risk of cholangiocarcinoma: an updated meta-analysis. Prz Gastroenterol. 2015;10:108-17.

86. Li J, Han T, Jing N, Li L, Zhang X, Ma F, et al. Obesity and the risk of cholangiocarcinoma: a meta-analysis. Tumour Biol. 2014;35:6831-8.

87. Wongjarupong N, Assavapongpaiboon B, Susantitaphong $P$, Cheungpasitporn W, Treeprasertsuk S, Rerknimitr R, et al. Non-alcoholic fatty liver disease as a risk factor for cholangiocarcinoma: a systematic review and meta-analysis. BMC Gastroenterol. 2017:17:149.

88. Bellentani S. The epidemiology of non-alcoholic fatty liver disease. Liver Int. 2017;37:81-4

89. Fava G, Alpini G, Rychlicki C, Saccomanno S, DeMorrow S, Trozzi L, et al. Leptin Enhances Cholangiocarcinoma Cell Growth. Cancer Res. 2008;68: 6752-61.

90. Alzahrani B, Iseli TJ, Hebbard LW. Non-viral causes of liver cancer: Does obesity led inflammation play a role? Cancer Lett. 2014;345:223-9.

91. Lewitt MS, Dent MS, Hall K. The Insulin-Like Growth Factor System in Obesity, Insulin Resistance and Type 2 Diabetes Mellitus. J Clin Med. 2014;3: 1561-74.

92. Gallagher E, LeRoith D. Minireview: IGF, insulin, and cancer. Endocrinology. 2011;152:2546-51

93. Weroha SJ, Haluska P. The insulin-like growth factor system in cancer. Endocrinol Metab Clin North Am. 2012;41:335-50 vi.

94. Alvaro D, Barbaro B, Franchitto A, Onori P, Glaser SS, Alpini G, et al. Estrogens and Insulin-Like Growth Factor 1 Modulate Neoplastic Cell Growth in Human Cholangiocarcinoma. Am J Pathol. 2006;169:877-88.

95. Targher G, Bertolini L, Padovani R, Rodella S, Zoppini G, Pichiri I, et al. Prevalence of non-alcoholic fatty liver disease and its association with cardiovascular disease in patients with type 1 diabetes. J Hepatol. 2010;53 713-8.

96. Aarnio M. Clinicopathological features and management of cancers in Lynch syndrome. Pathol Res Int. 2012;2012:350309.

97. Gunaydin M, Bozkurter Cil AT. Progressive familial intrahepatic cholestasis: diagnosis, management, and treatment. Hepatic Med Evid Res. 2018;10:95-104

98. Wan X, Xu Y, Qian J, Yang X, Wang A, He L, et al. Intraductal papillary neoplasm of the bile duct. World J Gastroenterol. 2013;19:8595-604.

99. Zabron A, Edwards R, Khan S. The challenge of cholangiocarcinoma: dissecting the molecular mechanisms of an insidious cancer. Model Mech. 2013;6:281-92.

100. Sugawara H, Yasoshima M, Katayanagi K, Kono N, Watanabe Y, Harada K, et al. Relationship between interleukin- 6 and proliferation and differentiation in cholangiocarcinoma. Histopathology. 1998;33:145-53. 
101. Isomoto H, Mott J, Kobayashi S, Werneburg N, Bronk S, Haan S, et al. Sustained IL-6/STAT-3 signaling in cholangiocarcinoma cells due to SOCS-3 epigenetic silencing. Gastroenterology. 2007;132:384-96.

102. Braconi C, Huang N, Patel T. MicroRNA-dependent regulation of DNA methyltransferase-1 and tumor suppressor gene expression by interleukin-6 in human malignant cholangiocytes. Hepatology. 2010;51:881-90.

103. Kobayashi S, Werneburg N, Bronk S, Kaufmann S, Gores G. Interleukin-6 contributes to $\mathrm{Mcl}-1$ up-regulation and TRAIL resistance via an Akt-signaling pathway in cholangiocarcinoma cells. Gastroenterology. 2005;128:2054-65.

104. Frampton $G$, Invernizzi $P$, Bernuzzi F, Pae H, Quinn M, Horvat D, et al. Interleukin-6-driven progranulin expression increases cholangiocarcinoma growth by an Akt-dependent mechanism. Gut. 2012;61:268-77.

105. Smout M, Laha T, Mulvenna J, Sripa B, Suttiprapa S, Jones A, et al. A granulinlike growth factor secreted by the carcinogenic liver fluke, Opisthorchis viverrini, promotes proliferation of host cells. PLoS Pathog. 2009;10:e1000611.

106. Bansal PS, Smout MJ, Wilson D, Cobos Caceres C, Dastpeyman M, Sotillo J, et al. Development of a Potent Wound Healing Agent Based on the Liver Fluke Granulin Structural Fold. J Med Chem. 2017;60:4258-66.

107. Haugen B, Karinshak SE, Mann VH, Popratiloff A, Loukas A, Brindley PJ, et al. Granulin Secreted by the Food-Borne Liver Fluke Opisthorchis viverrini Promotes Angiogenesis in Human Endothelial Cells. Front Med. 2018;5.

108. Tadlock L, Patel T. Involvement of p38 mitogen-activated protein kinase signaling in transformed growth of a cholangiocarcinoma cell line. Hepatology. 2001;33:43-51.

109. Brito A, Abrantes A, Encarnação J, Tralhão J, Botelho M. Cholangiocarcinoma: from molecular biology to treatment. Med Oncol. 2015;32:245.

110. Komori J, Marusawa H, Machimoto T, Endo Y, Kinoshita K, Kou T, et al. Activation-induced cytidine deaminase links bile duct inflammation to human cholangiocarcinoma. Hepatology. 2008;47:888-96.

111. You Z, Bei L, Cheng $L$, Cheng N. Expression of COX-2 and VEGF-C in cholangiocarcinomas at different clinical and pathological stages. Genet Mol Res. 2014;14:6239-46.

112. Zhang Z, Lai G, Sirica A. Celecoxib-induced apoptosis in rat cholangiocarcinoma cells mediated by Akt inactivation and Bax translocation. Hepatology. 2004;39:1028-37.

113. Han C, Leng J, Demetris A, Wu T. Cyclooxygenase-2 promotes human cholangiocarcinoma growth: evidence for cyclooxygenase-2-independent mechanism in celecoxib-mediated induction of p21waf1/cip1 and p27kip1 and cell cycle arrest. Cancer Res. 2004;64:1369-76.

114. Spirli C, Fabris L, Duner E, Fiorotto R, Ballardini G, Roskams T, et al. Cytokinestimulated nitric oxide production inhibits adenylyl cyclase and CAMPdependent secretion in cholangiocytes. Gastroenterology. 2003;124:737-53.

115. Prakobwong S, Pinlaor P, Charoensuk L, Khoontawad J, Yongvanit $P$, Hiraku $Y$, et al. The liver fluke Opisthorchis viverrini expresses nitric oxide synthase but not gelatinases. Parasitol Int. 2012;61:112-7.

116. Jaiswal M, LaRusso N, Shapiro R, Billiar T, Gores G. Nitric oxide-mediated inhibition of DNA repair potentiates oxidative DNA damage in cholangiocytes. Gastroenterology. 2001;120:190-9.

117. Ishimura N, Bronk S, Gores G. Inducible nitric oxide synthase up-regulates Notch-1 in mouse cholangiocytes: implications for carcinogenesis. Gastroenterology. 2005;128:1354-68.

118. Wu W, Zhang R, Shi X, Zhu M, Xu L, Zeng H, et al. Notch1 is overexpressed in human intrahepatic cholangiocarcinoma and is associated with its proliferation, invasiveness and sensitivity to 5-fluorouracil in vitro. Oncol Rep. 2014;31:2515-24.

119. Yoon H, Noh M, Kim B, Han J, Jang J, Choi S, et al. Clinicopathological significance of altered Notch signaling in extrahepatic cholangiocarcinoma and gallbladder carcinoma. World J Gastroenterol. 2011;17:4023-30.

120. Boulter L, Guest RV, Kendall TJ, Wilson DH, Wojtacha D, Robson AJ, et al. WNT signaling drives cholangiocarcinoma growth and can be pharmacologically inhibited. J Clin Invest. 2015;125:1269-85.

121. Monga SP. $\beta$-Catenin Signaling and Roles in Liver Homeostasis, Injury, and Tumorigenesis. Gastroenterology. 2015;148:1294-310.

122. Fernández-Barrena MG, Perugorria MJ, Banales JM. Novel IncRNA T-UCR as a potential downstream driver of the Wnt/ $\beta$-catenin pathway in hepatobiliary carcinogenesis. Gut. 2017;66:1177-8.

123. Jones $H$, Alpini $G$, Francis $H$. Bile acid signaling and biliary functions. Acta Pharm Sin B. 2015;5:123-8.

124. Keitel V, Reich M, Häussinger D. TGR5: Pathogenetic Role and/or Therapeutic Target in Fibrosing Cholangitis? Clin Rev Allergy Immunol. 2015; 48:218-25.
125. Reich M, Deutschmann K, Sommerfeld A, Klindt C, Kluge S, Kubitz R, et al. TGR5 is essential for bile acid-dependent cholangiocyte proliferation in vivo and in vitro. Gut. 2016;65:487-501.

126. Wang Y, Aoki H, Yang J, Peng K, Liu R, Li X, et al. The role of sphingosine 1phosphate receptor 2 in bile-acid-induced cholangiocyte proliferation and cholestasis-induced liver injury in mice. Hepatol Baltim Md. 2017;65:2005-18.

127. Liu R, Li X, Qiang X, Luo L, Hylemon PB, Jiang Z, et al. Taurocholate Induces Cyclooxygenase-2 Expression via the Sphingosine 1-phosphate Receptor 2 in a Human Cholangiocarcinoma Cell Line. J Biol Chem. 2015;290:30988-1002.

128. Dai J, Wang H, Dong Y, Zhang Y, Wang J. Bile Acids Affect the Growth of Human Cholangiocarcinoma via NF-kB Pathway. Cancer Invest. 2013;31:111-20.

129. Maroni L, Alpini G, Marzioni M. Cholangiocarcinoma development: The resurgence of bile acids: Maroni et al. Hepatology. 2014;60:795-7.

130. Chen C, Jochems PGM, Salz L, Schneeberger K, Penning LC, van de Graaf SFJ, et al. Bioengineered bile ducts recapitulate key cholangiocyte functions. Biofabrication. 2018;10:034103.

131. Alpini G, Ueno Y, Glaser SS, Marzioni M, Phinizy JL, Francis H, et al. Bile acid feeding increased proliferative activity and apical bile acid transporter expression in both small and large rat cholangiocytes. Hepatol Baltim Md. 2001;34:868-76.

132. Komichi D, Tazuma S, Nishioka T, Hyogo H, Chayama K. Glycochenodeoxycholate plays a carcinogenic role in immortalized mouse cholangiocytes via oxidative DNA damage. Free Radic Biol Med. 2005:39:1418-27.

133. Yoon J, Canbay A, Werneburg N, Lee S, Gores G. Oxysterols induce cyclooxygenase-2 expression in cholangiocytes: implications for biliary tract carcinogenesis. Hepatology. 2004;39:732-8.

134. O'Rourke CJ, Munoz-Garrido P, Aguayo EL, Andersen JB. Epigenome dysregulation in cholangiocarcinoma. Biochim Biophys Acta BBA - Mol Basis Dis. 1864;2018:1423-34.

135. Wangyang Z, Daolin J, Yi X, Zhenglong L, Lining H, Yunfu C, et al. NcRNAs and Cholangiocarcinoma. J Cancer. 2018;9:100-7.

136. Meng F, Henson R, Lang M, Wehbe H, Maheshwari S, Mendell J, et al. Involvement of human micro-RNA in growth and response to chemotherapy in human cholangiocarcinoma cell lines. Gastroenterology 130, 2113-2129. Gastroenterology. 2006;130:2113-29.

137. Meng F, Wehbe-Janek $H$, Henson $R$, Smith $H$, Patel T. Epigenetic regulation of microRNA- 370 by interleukin-6 in malignant human cholangiocytes. Oncogene. 2008;27:378-86.

138. Peng F, Jiang J, Yu Y, Tian R, Guo X, Li X, et al. Direct targeting of SUZ12/ ROCK2 by miR-200b/c inhibits cholangiocarcinoma tumourigenesis and metastasis. Br J Cancer. 2013;109:3092-104.

139. Iliopoulos D, Lindahl-Allen M, Polytarchou C, Hirsch HA, Tsichlis PN, Struhl K. Loss of miR-200 inhibition of Suz12 leads to polycomb-mediated repression required for the formation and maintenance of cancer stem cells. Mol Cell. 2010;39:761-72.

140. Alhopuro P, Björklund M, Sammalkorpi H, Turunen M, Tuupanen S, Biström $\mathrm{M}$, et al. Mutations in the circadian gene CLOCK in colorectal cancer. Mol Cancer Res. 2010;8:952-60.

141. Cadenas C, van de Sandt L, Edlund K, Lohr M, Hellwig B, Marchan R, et al. Loss of circadian clock gene expression is associated with tumor progression in breast cancer. Cell Cycle. 2014;13:3282-91.

142. Li B, Han Q, Zhu Y, Wang J, Jiang X. Down-regulation of miR-214 contributes to intrahepatic cholangiocarcinoma metastasis by targeting Twist. FEBS J. 2012;279:2393-8.

143. Wang L-J, He C-C, Sui X, Cai M-J, Zhou C-Y, Ma J-L, et al. MiR-21 promotes intrahepatic cholangiocarcinoma proliferation and growth in vitro and in vivo by targeting PTPN14 and PTEN. Oncotarget. 2015;6:5932-46.

144. Araki K, Shimura T, Suzuki H, Tsutsumi S, Wada W, Yajima T, et al. E/Ncadherin switch mediates cancer progression via TGF-B-induced epithelialto-mesenchymal transition in extrahepatic cholangiocarcinoma. Br J Cancer. 2011;105:1885-93.

145. Wheelock M, Shintani Y, Maeda M, Fukumoto Y, Johnson K. Cadherin switching. J Cell Sci. 2008;121:727-35.

146. Ogasawara S, Yano H, Higaki K, Takayama A, Akiba J, Shiota K, et al. Expression of angiogenic factors, basic fibroblast growth factor and vascular endothelial growth factor, in human biliary tract carcinoma cell lines. Hepatol Res. 2001;20:97-113.

147. Mancino A, Mancino M, Glaser S, Alpini G, Bolognese A, Izzo L, et al. Estrogens stimulate the proliferation of human cholangiocarcinoma by inducing the expression and secretion of vascular endothelial growth factor. Dig Liver Dis. 2008:41:156-63. 
148. Sampson L, Vickers S, Ying W, Phillips J. Tamoxifen-mediated growth inhibition of human cholangiocarcinoma. Cancer Res. 1997;57:1743-9.

149. Socoteanu M, Mott F, Alpini G, Frankel A. c-Met targeted therapy of cholangiocarcinoma. World J Gastroenterol. 2008;14:2990-4.

150. Leelawat K, Leelawat S, Tepaksorn P, Rattanasinganchan P, Leungchaweng A, Tohtong $\mathrm{R}$, et al. Involvement of c-Met/hepatocyte growth factor pathway in cholangiocarcinoma cell invasion and its therapeutic inhibition with small interfering RNA specific for c-Met. J Surg Res. 2006;136:78-84.

151. Sirica A. Role of ErbB family receptor tyrosine kinases in intrahepatic cholangiocarcinoma. World J Gastroenterol. 2008;14:7033-58.

152. Harnois D, Que F, Celli A, LaRusso N, Gores G. BCl-2 is overexpressed and alters the threshold for apoptosis in a cholangiocarcinoma cell line. Hepatology. 1997;26:884-90.

153. Kim J, Han S, Lee S, Baek Y, Kim H, Kim J, et al. Sodium iodide symporter and phosphatase and tensin homolog deleted on chromosome ten expression in cholangiocarcinoma analysis with clinicopathological parameters. Gut Liver. 2012;6:374-80.

154. Lacoste C, Herve J, Moniaux N, Faitot F, Dos Santos A, Valogne Y, et al. The sodium iodide symporter enhances cell migration and invasion. J Hepatol. 2010;52:S18.

155. Kubo Y, Aishima S, Tanaka Y, Shindo K, Mizuuchi Y, Abe K, et al. Different expression of glucose transporters in the progression of intrahepatic cholangiocarcinoma. Hum Pathol. 2014;45:1610-7.

156. Cadamuro M, Nardo G, Indraccolo S, Dall'Olmo L, Sambado L, Moserle L, et al. Platelet-derived growth factor-D and Rho GTPases regulate recruitment of cancer-associated fibroblasts in cholangiocarcinoma. Hepatology. 2013; 58:1042-53.

157. Sun Q, Zhao C, Xia L, He Z, Lu Z, Liu C, et al. High expression of matrix metalloproteinase-9 indicates poor prognosis in human hilar cholangiocarcinoma. Int J Clin Exp Pathol. 2014;7:6157-64.

158. Zhao X, Li J, Shen Q, Yu B. miR-21 targets MMP-7 and promotes perineural invasion of cholangiocarcinoma. Int J Clin Exp Pathol. 2017;10:10.

159. Raggi C, Correnti M, Sica A, Andersen JB, Cardinale V, Alvaro D, et al. Cholangiocarcinoma stem-like subset shapes tumor-initiating niche by educating associated macrophages. J Hepatol. 2017;66:102-15.

160. Moeini A, Sia D, Bardeesy N, Mazzaferro V, Llovet JM. Molecular Pathogenesis and Targeted Therapies for Intrahepatic Cholangiocarcinoma. Clin Cancer Res. 2016;22:291-300.

161. Fava G, Lorenzini I. Molecular pathogenesis of cholangiocarcinoma. Int J Hepatol. 2012;2012:630543.

162. Sia D, Tovar V, Moeini A, Llovet J. Intrahepatic cholangiocarcinoma: pathogenesis and rationale for molecular therapies. Oncogene. 2013;32: 4861-70.

163. Reeves M, DeMatteo R. Genes and viruses in hepatobiliary neoplasia. Semin Surg Oncol. 2000;19:84-93.

164. Obama K, Satoh S, Hamamoto R, Sakai Y, Nakamura Y, Furukawa Y. Enhanced expression of RAD51 associating protein-1 is involved in the growth of intrahepatic cholangiocarcinoma cells. Clin Cancer Res. 2008; 14:1333-9.

165. Nakanuma S, Tajima H, Okamoto K, Hayashi H, Nakagawara H, Onishi I, et al. Tumor-derived trypsin enhances proliferation of intrahepatic cholangiocarcinoma cells by activating protease-activated receptor-2. Int J Oncol. 2010;36:793-800.

166. Lempinen M, Isoniemi H, Mäkisalo H, Nordin A, Halme L, Arola J, et al. Enhanced detection of cholangiocarcinoma with serum trypsinogen-2 in patients with severe bile duct strictures. J Hepatol. 2007;47:677-83.

167. Chong D, Zhu A. The landscape of targeted therapies for cholangiocarcinoma: current status and emerging targets. Oncotarget. 2016; 7:46750-67.

168. Ross J, Wang K, Gay L, Al-Rohil R, Rand J, Jones D, et al. New routes to targeted therapy of intrahepatic cholangiocarcinomas revealed by nextgeneration sequencing. Oncologist. 2014;19:235-42.

169. Weizmann Institute of Science. GeneCards. Gene cards: the human gene database. 2018. http://www.genecards.org/. Accessed 30 Oct 2018.

170. Zweers SJLB, Booij KAC, Komuta M, Roskams T, Gouma DJ, Jansen PLM, et al. The human gallbladder secretes fibroblast growth factor 19 into bile: Towards defining the role of fibroblast growth factor 19 in the enterobiliary tract. Hepatology. 2012;55:575-83

171. Zhai C, Li Y, Mascarenhas C, Lin Q, Li K, Vyrides I, et al. The function of ORAOV1/LTO1, a gene that is overexpressed frequently in cancer: essential roles in the function and biogenesis of the ribosome. Oncogene. 2014;33: 484-94.

172. Sia D, Hoshida Y, Villanueva A, Roayaie S, Ferrer J, Tabak B, et al. Integrative molecular analysis of intrahepatic cholangiocarcinoma reveals 2 classes that have different outcomes. Gastroenterology. 2013;144:829-40.

173. Melum E, Karlsen T, Schrumpf E, Beergguist A, Thorsby E, Boberg K, et al. Cholangiocarcinoma in primary sclerosing cholangitis is associated with NKG2D polymorphisms. Hepatology. 2008;47:90-6.

174. Dusheiko G. Hepatitis C. In: Dooley JS, Lok ASF, Garcia-Tsao G, Pinzani M, editors. Sherlock's Diseases of the Liver and Biliary System. Chichester: Wiley; 2018. p. 436-67.

175. Hutin $Y$, Nasrullah M, Easterbrook P, Nguimfack BD, Burrone E, Averhoff F, et al. Access to Treatment for Hepatitis B Virus Infection - Worldwide, 2016. MMWR Morb Mortal Wkly Rep. 2018;67:773-7.

176. Younossi ZM, Koenig AB, Abdelatif D, Fazel Y, Henry L, Wymer M. Global epidemiology of nonalcoholic fatty liver disease-Meta-analytic assessment of prevalence, incidence, and outcomes: HEPATOLOGY, Vol. XX, No. X 2016. Hepatology. 2016;64:73-84.

177. Lindor KD, Kowdley KV, Harrison ME. ACG Clinical Guideline: Primary Sclerosing Cholangitis. Am J Gastroenterol. 2015;110:646.

178. Tai D, Wells K, Arcaroli J, Vanderbilt C, Aisner DL, Messersmith WA, et al. Targeting the WNT Signaling Pathway in Cancer Therapeutics. Oncologist. 2015;20:1189-98.

179. Cigliano A, Wang J, Chen X, Calvisi DF. Role of the Notch signaling in cholangiocarcinoma. Expert Opin Ther Targets. 2017;21:471-83.

180. Liu L, Cao Y, Chen C, Zhang X, McNabola A, Wilkie D, et al. Sorafenib Blocks the RAF/MEK/ERK Pathway, Inhibits Tumor Angiogenesis, and Induces Tumor Cell Apoptosis in Hepatocellular Carcinoma Model PLC/PRF/5. Cancer Res. 2006;66:11851-8.

181. Malka D, Cervera P, Foulon S, Trarbach $T$, de la Fouchardière C, Boucher E, et al. Gemcitabine and oxaliplatin with or without cetuximab in advanced biliary-tract cancer (BINGO): a randomised, open-label, non-comparative phase 2 trial. Lancet Oncol. 2014;15:819-28.

182. Lee J, Park S, Chang H, Kim J, Choi H, Lee M, et al. Gemcitabine and oxaliplatin with or without erlotinib in advanced biliary-tract cancer: a multicentre, open-label, randomised, phase 3 study. Lancet Oncol. 2012; 13:181-8.

183. Leone F, Marino D, Cereda S, Filippi R, Belli C, Spadi R, et al. Panitumumab in combination with gemcitabine and oxaliplatin does not prolong survival in wild-type KRAS advanced biliary tract cancer: A randomized phase 2 trial (Vecti-BIL study): GEMOX and Panitumumab in WT KRAS BTC. Cancer. 2016; 122:574-81.

184. Moehler M, Maderer A, Schimanski C, Kanzler S, Denzer U, Kolligs F, et al. Gemcitabine plus sorafenib versus gemcitabine alone in advanced biliary tract cancer: a double-blind placebo-controlled multicentre phase II AIO study with biomarker and serum programme. Eur J Cancer. 2014;50: 3125-35.

185. Valle JW, Wasan H, Lopes A, Backen AC, Palmer DH, Morris K, et al. Cediranib or placebo in combination with cisplatin and gemcitabine chemotherapy for patients with advanced biliary tract cancer (ABC-03): a randomised phase 2 trial. Lancet Oncol. 2015;16:967-78.

186. Valle J, Borbath I, Khan S, Huguet F, Gruenberger T, Arnold D, et al. Biliary cancer: ESMO clinical practice guidelines for diagnosis, treatment and follow-up. Ann Oncol. 2016;27:v28-37.

Ready to submit your research? Choose BMC and benefit from:

- fast, convenient online submission

- thorough peer review by experienced researchers in your field

- rapid publication on acceptance

- support for research data, including large and complex data types

- gold Open Access which fosters wider collaboration and increased citations

- maximum visibility for your research: over $100 \mathrm{M}$ website views per year

At BMC, research is always in progress.

Learn more biomedcentral.com/submissions 